\title{
JiSEA
}

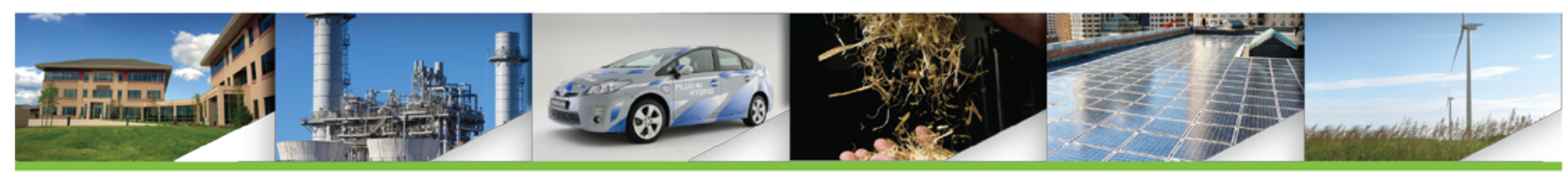

\section{Low-Carbon Natural Gas for Transportation: Well-to-Wheels Emissions and Potential Market Assessment in California}

Michael Penev, Marc Melaina, Brian Bush, Matteo Muratori, Ethan Warner, and Yuche Chen

National Renewable Energy Laboratory

Prepared for the Southern California Gas Company by the Joint Institute for Strategic Energy Analysis

The Joint Institute for Strategic Energy Analysis is operated by the Alliance for Sustainable Energy, LLC, on behalf of the U.S. Department of Energy's National Renewable Energy Laboratory, the University of Colorado-Boulder, the Colorado School of Mines, the Colorado State University, the Massachusetts Institute of Technology, and Stanford University.

Technical Report

NREL/TP-6A50-66538

December 2016

Contract No. DE-AC36-08G028308

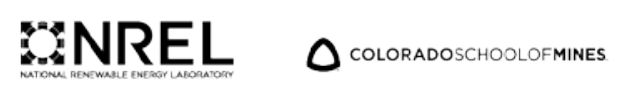




\section{Low-Carbon Natural Gas for Transportation: Well-to-Wheels Emissions and Potential Market Assessment in California}

Michael Penev, Marc Melaina, Brian Bush, Matteo Muratori, Ethan Warner, and Yuche Chen National Renewable Energy Laboratory

Prepared under Task No. WWJI.1019

The Joint Institute for Strategic Energy Analysis is operated by the Alliance for Sustainable Energy, LLC, on behalf of the U.S. Department of Energy's National Renewable Energy Laboratory, the University of Colorado-Boulder, the Colorado School of Mines, the Colorado State University, the Massachusetts Institute of Technology, and Stanford University.

JISEA $^{\circledR}$ and all JISEA-based marks are trademarks or registered trademarks of the Alliance for Sustainable Energy, LLC.

The Joint Institute for Strategic Energy Analysis 15013 Denver West Parkway Golden, CO 80401 303-275-3000 • www.jisea.org
Technical Report

NREL/TP-6A50-66538

December 2016

Contract No. DE-AC36-08G028308 


\section{NOTICE}

This report was prepared as an account of work sponsored by an agency of the United States government. Neither the United States government nor any agency thereof, nor any of their employees, makes any warranty, express or implied, or assumes any legal liability or responsibility for the accuracy, completeness, or usefulness of any information, apparatus, product, or process disclosed, or represents that its use would not infringe privately owned rights. Reference herein to any specific commercial product, process, or service by trade name, trademark, manufacturer, or otherwise does not necessarily constitute or imply its endorsement, recommendation, or favoring by the United States government or any agency thereof. The views and opinions of authors expressed herein do not necessarily state or reflect those of the United States government or any agency thereof.

Available electronically at SciTech Connect: http:/www.osti.gov/scitech

Available for a processing fee to U.S. Department of Energy and its contractors, in paper, from:

U.S. Department of Energy

Office of Scientific and Technical Information

P.O. Box 62

Oak Ridge, TN 37831-0062

OSTI: http://www.osti.gov

Phone: 865.576 .8401

Fax: 865.576.5728

Email: reports@osti.gov

Available for sale to the public, in paper, from:

U.S. Department of Commerce

National Technical Information Service

5301 Shawnee Road

Alexandria, VA 22312

NTIS: http://www.ntis.gov

Phone: 800.553 .6847 or 703.605 .6000

Fax: 703.605.6900

Email: orders@ntis.gov 


\section{Acknowledgments}

This report has benefited from comments and discussions from various reviewers and subject experts. In particular, the authors are grateful for review comments on an earlier version of the report from Anil Prabhu (California Air Resources Board), Fan Tong (Carnegie Mellon University), and Rosa Dominguez-Faus (University of California, Davis). The authors would also like to acknowledge Keith Kronin (University of Wisconsin-Madison), Patricia Statwick (Joint Institute for Strategic Energy Analysis), and Yongling Sun (California Air Resources Board) for their assistance and support during this analysis. Finally, the report has been improved through guidance and comments provided by the report sponsors, Jeff Reed and Ron Kent of the Southern California Gas Company, who supported this work as a component of the natural gas research portfolio of the Joint Institute for Strategic Energy Analysis. 


\section{List of Acronyms}

$\mathrm{CNG}$

CNGV

DOE

gge

GHG

GREET

$\mathrm{H} 2 \mathrm{~A}$

HDV

LCNG

LDV

MDV

MMBtu

TTW

WTT

WTW

WWTP compressed natural gas

compressed natural gas vehicle

U.S. Department of Energy

gasoline gallon equivalent

greenhouse gas

Greenhouse Gases, Regulated Emissions, and Energy Use in Transportation (Argonne National Laboratory model)

Hydrogen Analysis (DOE model)

heavy-duty vehicle

low-carbon natural gas

light-duty vehicle

medium-duty vehicle

million British thermal units

tank-to-wheels

well-to-tank

well-to-wheels

waste water treatment plant 


\section{Abstract}

The abundance of low-cost natural gas in the United States contributed to lower market price, reduced dependence on imported oil, and the decoupling of the price of natural gas from that of petroleum. These changed market conditions tend to favor the use of natural gas in many sectors, including transportation applications, especially for medium- and heavy-duty vehicles with high annual miles traveled. In addition, escalating pressure on the transportation sector to reduce petroleum consumption, greenhouse gas (GHG) emissions, and criteria pollutant emissions suggests that a favorable policy environment may support alternative fuels. These policy influences are particularly pronounced in California, where severe NOx reduction requirements, the zero emission vehicle mandate, the Low Carbon Fuel Standard, California's aggressive GHG reduction goal for 2050 (80\% GHG emissions reductions by 2050), and favorable customer perception are positioning California as an early mover in the adoption of alternative fuel vehicles.

In this context, however, one concern over the long-term viability of natural gas as a transportation fuel is the uncertainty of whether low-carbon natural gas (LCNG) supplies will be substituted for fossil natural gas to reduce the environmental burden of the transportation sector and transition toward a sustainable future in line with long-term GHG reduction goals. LCNG can be produced from a variety of sources, such as anaerobic digestion biogas (e.g., landfill gas, wastewater treatment plant, or agricultural waste), gasification of woody and herbaceous biomass, and methanation of low-carbon hydrogen.

This report improves the understanding of the long-term techno-economic potential of LCNG supply pathways by exploring transportation market adoption potential through 2030 in California. Techno-economic assessments of fourteen different pathways are proposed to compare the resource availability, capacity, cost, and GHG emissions of select LCNG production pathways. The study analyzes the use of fuel from these pathways in light-, medium-, and heavyduty vehicle applications. Economic and lifecycle GHG emissions analyses suggest that landfill gas resources are an attractive and relatively abundant resource from a cost and GHG reduction potential, followed by wastewater treatment plants and gasification of woody and herbaceous biomass coupled to methanation. Total LCNG production potential in California is assessed to be in line with total natural gas demand for transportation, and could result in a successful scenario for future natural gas vehicle adoption by 2030 across light-, medium-, and heavy-duty vehicle markets ( 110 trillion Btu/year). 


\section{Table of Contents}

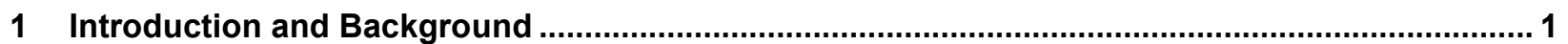

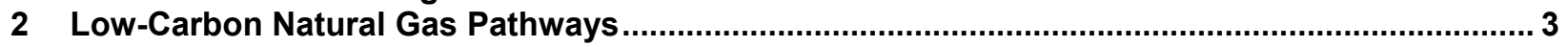

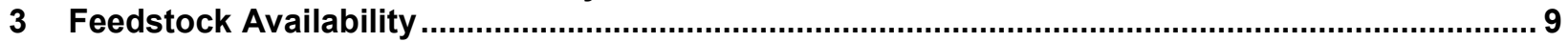

4 Projected Transportation Fuel Demand Analysis .................................................................... 12

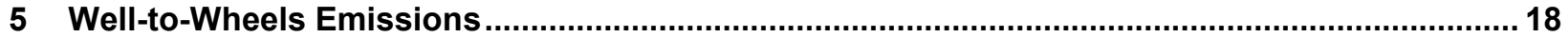

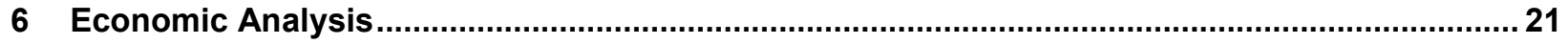

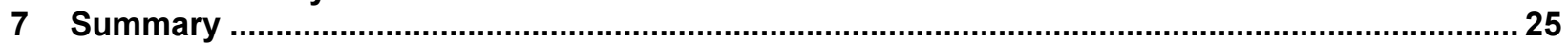

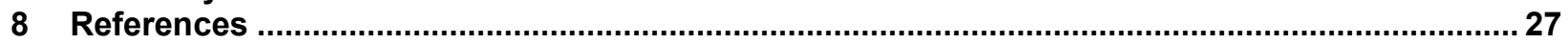

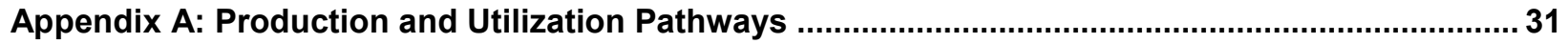

\section{List of Figures}

Figure 1. Diagram of LCNG pathways studied

Figure 2. GHG emissions reduction (compared to conventional $\mathrm{CNG}$ ) and production cost for different

LCNG pathways

Figure 3. California's LCNG feedstock resources by county and feedstock type ................................... 11

Figure 4. Projected natural gas consumption for transportation applications in 2030 by county and vehicle

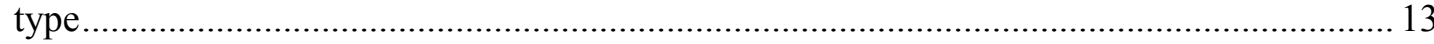

Figure 5. Potential LCNG supply and CNG demand for transportation applications in California ........... 14

Figure 6. Supply and demand for LCNG transportation applications in California by county .................. 15

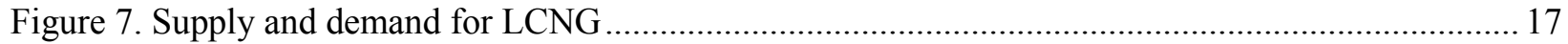

Figure 8. Well-to-tank GHG emissions of conventional CNG and selected LCNG pathways.................. 18

Figure 9. Well-to-wheels GHG emissions of conventional and low-carbon fuel pathways for various

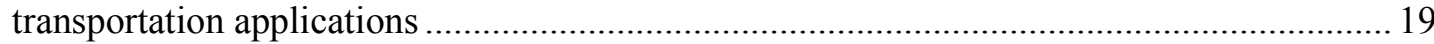

Figure 10. Abundance and well-to-wheels GHG emissions of selected LCNG pathways for different

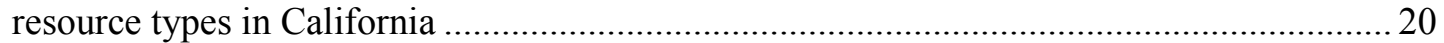

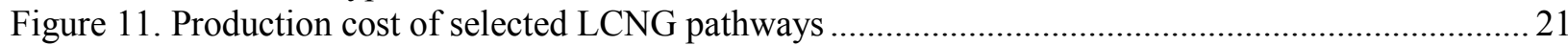

Figure 12. Levelized financial analysis for 70,000 gge/month LCNG stations (top) and 30,000 gge/month

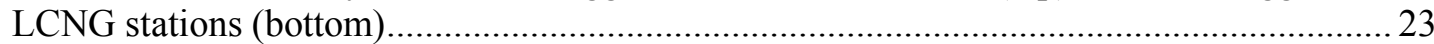

Figure 13. Breakdown of total LCNG retail sale price for selected pathways......................................... 24

\section{List of Tables}

Table 1. LCNG Plant Capacity and Cost, Production Cost (for Point of Production, Not Including Distribution and Retail Costs), and Well-to-Wheels GHG Emissions for Different LCNG Pathways

Table 2. Total Availability of Select LCNG Feedstock Types in California .......................................... 10

Table 3. Projected California CNG Vehicles Stock, Miles Traveled, Fuel Efficiency, and Consumption in

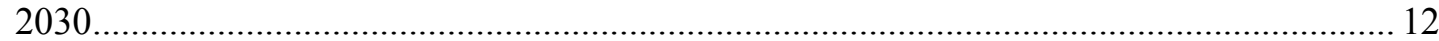

Table 4. LCNG Retail Refueling Station Characteristics ................................................................... 22

Table 5. Summary of Retail Infrastructure Costs............................................................................................. 24 


\section{Introduction and Background}

The decline of natural gas prices in the United States - following recent advancements in extraction technology that significantly increased the domestic economically recoverable natural gas resources - favors the adoption of natural gas vehicles compared to conventional gasoline or diesel vehicles. The decoupling of natural gas and crude oil price projections, due in part to abundance of domestic natural gas resources in the United States, suggests significant opportunities for near-term and potentially long-term competitive advantage for natural gas as a transportation fuel. In addition, escalating pressure on the transportation sector to reduce petroleum consumption, GHG emissions, and criteria pollutant emissions suggests that a favorable policy environment may support alternative low-carbon fuels. These policy influences will be particularly pronounced in Southern California markets, due to severe NOx reduction requirements as well as the zero emission vehicles mandate, the Low Carbon Fuel Standard, and California's aggressive GHG reduction goal for 2050 (80\% GHG emissions reductions by 2050 [California Office of the Governor 2015]). In this context, one of the concerns of an increased market share for natural gas as a transportation fuel is the degree to which production can be decarbonized to meet long-term GHG reduction goals.

LCNG - a gas with the same basic characteristics of natural gas but with a lower carbon content - can be obtained by either replacing or supplementing fossil natural gas with hydrogen produced from renewable energy sources (e.g., electrolysis using electricity from renewable sources) or with renewable biogas (e.g., bio-methane from the anaerobic digestion of biomass waste). Renewable biogas can be produced from a variety of sources, most notably urban and agricultural wastes, providing potential additional co-benefits such as waste management.

Transportation application has been suggested as a final use for LCNG, given the limited alternatives available to decarbonize that sector. Several studies have looked at the potential for using bio-methane as a transportation fuel, showing promising potential and identifying a development path with relatively low financial and technical risks (Åhman 2010; Mintz et al. 2010; Thamsiriroj, Smyth, and Murphy 2011; Han, Mintz, and Wang 2011; Patterson et al. 2011). Bio-methane has the potential to deliver greater environmental benefits than either biodiesel or first generation bioethanol (Smyth, Murphy, and O'Brien 2009; Murphy and Power 2009). Bordelanne et al. (2011) show that bio-methane brings the GHG emission levels, over the course of the vehicle life cycle, down to more than $80 \%$ compared to a gasoline vehicle. However, to take advantage of existing infrastructure, bio-methane needs to be upgraded to adequate quality before injection into existing pipelines or use in CNG applications. Ultimately, LCNG use for transportation applications faces the same obstacle as CNG, most notably lack of refueling infrastructure and barriers to transition away from well-established and affordable petroleum-based liquid fuels.

This report improves the understanding of the long-term techno-economic potential of LCNG supply pathways by examining transportation market adoption potential through 2030 in California. Techno-economic assessments are proposed to compare the resource availability, capacity, cost, and GHG emissions of several LCNG production pathways. The study also analyzes the use of fuel from these pathways in light-, medium-, and heavy-duty vehicle applications. 
The remainder of this report is organized as follows:

- Section 2 describes fourteen alternative pathways to produce LCNG and identifies five that promise significant GHG emission reductions that are analyzed in more detail in the remainder of the report.

- Section 3 analyzes the availability of different feedstock options in California for the selected LCNG pathways.

- Section 4 compares the potential supply of LCNG fuels to projected transportation fuel demand in California, based on recent estimates.

- Section 5 estimates the well-to-wheels emissions of LCNG for different pathways based on CA-GREET 2.0 (CARB 2016).

- Section 6 analyzes the economics of producing and dispensing LCNG for the selected pathways.

- Section 7 provides concluding remarks, a summary, and suggestions for future work. 


\section{Low-Carbon Natural Gas Pathways}

Significant research and development, demonstration, and analytical works have been completed on a wide range of conventional and advanced LCNG pathways for use in transportation applications (i.e., compressed natural gas vehicles). These include supplemented use, in which biogas or hydrogen produced by electrolysis utilizing renewable energy sources ("low-carbon hydrogen") is blended into the natural gas delivery infrastructure for use in vehicles and other end-uses (Melaina et al. 2013), as well as dedicated delivery systems, which directly provide LCNG fuel to vehicles and other consumers. This study analyzes a range of potential pathways for reducing the carbon intensity of natural gas, depicted in Figure 1, including:

- Anaerobic digestion biogas upgraded to pipeline quality gas and injected in the pipeline network. This upgraded biogas, also called renewable natural gas, is comprised primarily of methane and carbon dioxide. Besides pipeline injection, renewable natural gas could be collected and delivered with compressed gas tube trailers to retail stations, but this option is not included in this analysis. Renewable natural gas can be produced from a variety of pathways:

- Wastewater treatment plant (WWTP) anaerobic digestion (Pathway 1). Solids from WWTPs are concentrated to generate sludge, which is converted to biogas in an anaerobic digester and subsequently upgraded to pipeline quality gas.

○ Landfill gas (Pathway 2). Biogas produced by anaerobic digestion of organic material in landfills is captured and subsequently upgraded to pipeline quality gas.

- Agricultural waste or livestock manure anaerobic digestion (Pathway 3). Agricultural wastes (such as poultry, cattle, and hog manure) are converted into biogas within an anaerobic digester, which is subsequently upgraded to pipeline quality gas. CA-GREET $2.0^{1}$, the life-cycle assessment tool used in this study, accounts for GHG emissions based on baseline animal manure configuration. Note that analysis of this pathway was bifurcated to represent two types of anaerobic digesters currently used. In one case, anaerobic digesters' products are currently vented to the atmosphere (Pathway 3a). Due to the high GHG potential of methane, reducing methane emissions from such systems by capturing and using methane previously vented allows for significant GHG emissions reductions. The second case (Pathway 3 b) involves a digester with flared exhaust. This type of digester yields lower GHG reductions as methane emissions are not avoided by the LCNG production process.

- Gasification of woody and herbaceous biomass, such as agricultural residues, urban wood waste, and woody forest biomass. While other biomass resources can also be used in gasification processes, the present analysis considers woody and herbaceous biomass as most representative for this pathway. The syngas produced (a mixture primarily of carbon monoxide and hydrogen) can be converted to different energy carriers for final use:

$\circ$ Methane - produced by gasifying biomass to syngas and then converting the syngas into methane in a methanation reactor, followed by direct injection into

\footnotetext{
${ }^{1}$ Greenhouse Gases, Regulated Emissions, and Energy Use in Transportation (GREET) model (ANL 2015), relying on updated and regionalized results from the California GREET 2.0 model (CARB 2016).
} 
natural gas pipelines (Pathways 4 and 5, for current and future technology cost, respectively).

- Hydrogen - produced by gasifying biomass to syngas followed by a shift reaction to increase hydrogen content. Hydrogen is then blended into natural gas pipelines at low volumes: 5\% or less (Pathways 12 and 13, for current and future technology cost, respectively).

- Methane produced from low-carbon hydrogen. Hydrogen produced in a central facility by electrolysis using electricity produced from renewable sources is converted into methane by combination with carbon dioxide in a methanation reactor and injected into natural gas pipelines (Pathways 6 and 7, for current and future technology cost, respectively).

- Low-carbon hydrogen blend. Hydrogen produced by electrolysis using electricity produced from renewable sources is injected into natural gas pipelines or blended with natural gas vehicle fuel. Low-carbon hydrogen can be produced with different pathways:

- Central electrolysis - electrolyzing water centrally (for example, near a grid substation) and injecting hydrogen into natural gas pipelines at about $5 \%$ by volume (Pathways 10 and 11, for current and future technology cost, respectively).

- Distributed electrolysis - electrolysis at retail fueling stations and blending the hydrogen with compressed natural gas (CNG) at about $20 \%$ by volume ${ }^{2}$ (Pathways 8 and 9, for current and future technology cost, respectively).

- Conventional CNG (Pathway 14). This is the baseline pathway using fossil natural gas against which the other pathways are compared.

\footnotetext{
${ }^{2}$ Some commercial blends of compressed hydrogen and natural gas for transportation fuel have been called Hythane.
} 


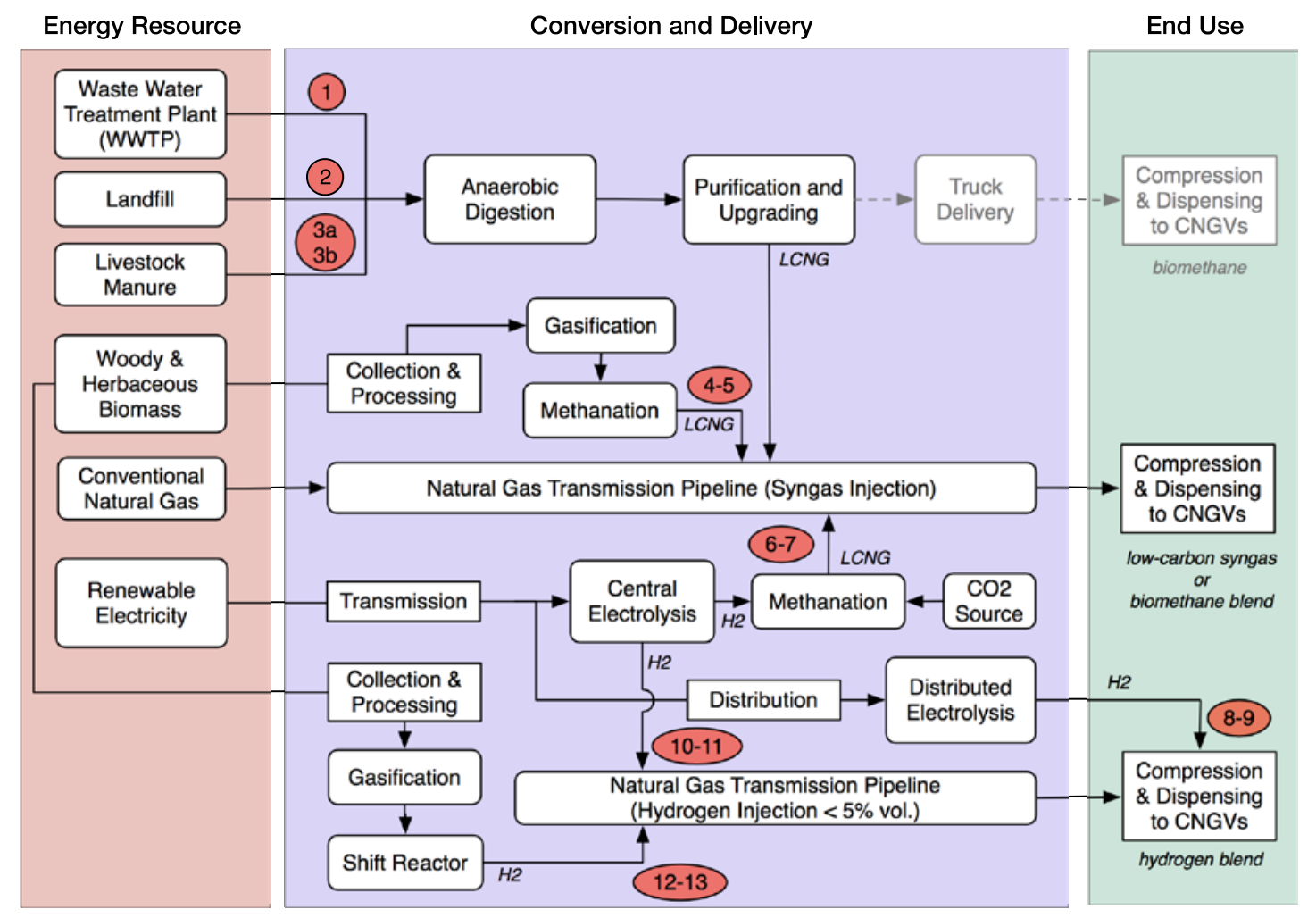

Figure 1. Diagram of LCNG pathways studied

Table 1 provides cost and GHG emissions metrics for the fourteen pathways and the conventional CNG baseline. ${ }^{3}$ Estimates for LCNG plant capacity and up-front plant costs as well as resulting cost per million British thermal units (MMBtu) and gallon of gasoline equivalent (gge) of final product are shown for each of the pathways. Well-to-wheels GHG emissions are shown on a grams of $\mathrm{CO}_{2}$ equivalent per gasoline gallon equivalent (g/gge) basis. Each pathway has different average plant capacity due to the assumed technologies used. For example, livestock manure anaerobic digesters tend to be relatively small compared to biomass gasification plants or central electrolysis plants, due to the nature of the processes involved and the feedstock used. Costs refer to $\mathrm{N}^{\text {th }}$-of-a-kind plants benefitting from economies of scale and streamlined permitting and installation processes. For each pathway, GHG emissions are calculated using the CA-GREET 2.0 (CARB 2016). Cost of fuel production and other metrics, including capacity and conversion efficiency, were derived using the U.S. Department of Energy's (DOE) Hydrogen Analysis (H2A) model (DOE 2015), which provides a detailed and standardized financial framework that can be applied consistently to multiple fuel products and supply pathways. Note that the central electrolysis with $\mathrm{CO}_{2}$ methanation pathways (6 and 7) do not have a GHG emissions estimate because the carbon dioxide source is undefined and its carbon intensity basis is uncertain (see Appendix A for additional details). These two pathways are not considered further in this report.

\footnotetext{
${ }^{3}$ Note that the fourteen potential pathways for reducing the carbon intensity of natural gas shown in the table are numbered 1 through 13. Pathway 3 is subdivided into two pathways, 3a and 3b, for a total of fourteen LCNG pathways. Item number 14 in the table is the baseline case of conventional CNG, against which the preceding fourteen pathways are compared.
} 
Table 1. LCNG Plant Capacity and Cost, Production Cost (for Point of Production, Not Including Distribution and Retail Costs), and Well-to-Wheels GHG Emissions for Different LCNG Pathways

\begin{tabular}{|c|c|c|c|c|c|c|}
\hline \multicolumn{2}{|r|}{ LCNG Production Pathway } & \multirow{2}{*}{$\begin{array}{c}\text { Plant } \\
\text { Capacity } \\
\text { (MMBtu/h) } \\
67\end{array}$} & \multirow{2}{*}{\begin{tabular}{|l}
$\begin{array}{c}\text { Plant } \\
\text { Cost } \\
\text { (\$M/plant) }\end{array}$ \\
4.03
\end{tabular}} & \multirow{2}{*}{$\begin{array}{c}\text { LCNG } \\
\text { Cost } \\
\text { (\$/M/MBtu) } \\
20.63\end{array}$} & \multirow{2}{*}{$\begin{array}{l}\text { LCNG } \\
\text { Cost } \\
(\$ / g g e)\end{array}$} & \multirow{2}{*}{$\begin{array}{c}\text { GHG } \\
\text { Emissions } \\
(\mathrm{g} / \mathrm{gge}) \\
2,119\end{array}$} \\
\hline 1 & $\begin{array}{l}\text { WWTP sludge digester \& } \\
\text { injection in pipelines }\end{array}$ & & & & & \\
\hline 2 & $\begin{array}{l}\text { Landfill gas cleanup \& } \\
\text { injection in pipelines }\end{array}$ & 120 & 8.95 & 3.84 & 0.44 & 2,874 \\
\hline $3 a$ & $\begin{array}{l}\text { Agricultural anaerobic } \\
\text { digester \& pipeline injection } \\
\text { (vented) }\end{array}$ & 10 & 2.79 & 10.01 & 1.14 & $(27,913)$ \\
\hline $3 b$ & $\begin{array}{l}\text { Agricultural anaerobic } \\
\text { digester \& pipeline injection } \\
\text { (flared) }\end{array}$ & 10 & 2.79 & 10.01 & 1.14 & 10,358 \\
\hline 4 & $\begin{array}{l}\text { Biomass gasification to } \\
\text { syngas \& methanation }(\mathrm{CT})^{\text {a }}\end{array}$ & 784 & 121.09 & 16.54 & 1.89 & 1,278 \\
\hline 5 & $\begin{array}{l}\text { Biomass gasification to } \\
\text { syngas \& methanation }(F T)^{b}\end{array}$ & 782 & 129.75 & 15.32 & 1.75 & 1,278 \\
\hline 6 & $\begin{array}{l}\text { Central electrolysis with } \mathrm{CO}_{2} \\
\text { methanation }(\mathrm{CT})^{c}\end{array}$ & 272 & 118.89 & 40.68 & 4.64 & - \\
\hline 7 & $\begin{array}{l}\text { Central electrolysis with } \mathrm{CO}_{2} \\
\text { methanation }(\mathrm{FT})^{\mathrm{c}}\end{array}$ & 272 & 57.41 & 32.98 & 3.76 & - \\
\hline 8 & $\begin{array}{l}\text { Distributed electrolysis \& tank } \\
\text { blending ( } 20 \% \text { by vol.) (CT) }\end{array}$ & 100 & 3.23 & 14.28 & 1.63 & 8,679 \\
\hline 9 & $\begin{array}{l}\text { Distributed electrolysis \& tank } \\
\text { blending ( } 20 \% \text { by vol.) (FT) }\end{array}$ & 100 & 1.40 & 13.78 & 1.57 & 8,679 \\
\hline 10 & $\begin{array}{l}\text { Central electrolysis \& pipeline } \\
\text { blending ( } 5 \% \text { by vol.) (CT) }\end{array}$ & 16,355 & 102.60 & 12.79 & 1.46 & 9,042 \\
\hline 11 & $\begin{array}{l}\text { Central electrolysis \& pipeline } \\
\text { blending ( } 5 \% \text { by vol.) (FT) }\end{array}$ & 16,355 & 41.40 & 12.68 & 1.45 & 9,042 \\
\hline 12 & $\begin{array}{l}\text { Gasification to } \mathrm{H}_{2} \& \text { pipeline } \\
\text { blending ( } 5 \% \text { by vol.) (CT) }\end{array}$ & 47,114 & 125.84 & 12.44 & 1.42 & 9,067 \\
\hline 13 & $\begin{array}{l}\text { Gasification to } \mathrm{H}_{2} \& \text { pipeline } \\
\text { blending ( } 5 \% \text { by vol.) (FT) }\end{array}$ & 46,969 & 118.08 & 12.40 & 1.41 & 9,067 \\
\hline 14 & Conventional CNG (Baseline) & - & - & $2.62^{\mathrm{d}}$ & $0.30^{d}$ & 9,163 \\
\hline
\end{tabular}

For each of the gasification and electrolysis pathways, metrics in Table 1 are shown in pairs for current technology (CT) as well as future technology (FT), based upon specific DOE technology improvement goals (note that costs will change across these pairs of pathways, while other technology assumptions and GHG emissions remain constant). For cases in which hydrogen is 
blended with natural gas, the values shown refer to the final blended product; for example, Pathway 6 metrics refer to the characteristics of a product that is $5 \%$ hydrogen and $95 \%$ conventional natural gas by volume. ${ }^{4}$ Figure 2 shows the relative GHG reductions compared to CNG (Baseline, assumed at 9,163 g/gge according to CA-GREET 2.0.) versus the production cost for each LCNG pathway considered.

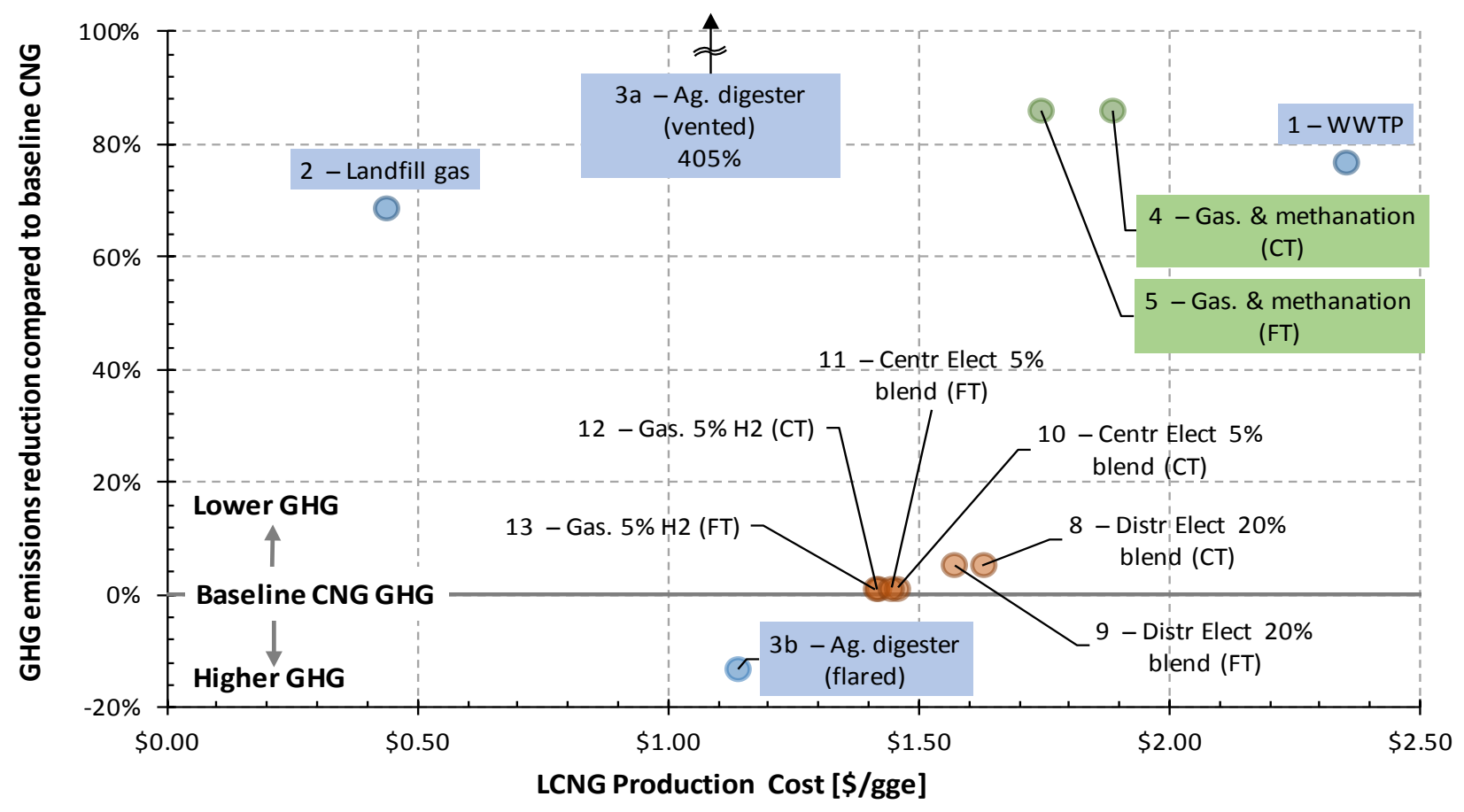

Figure 2. GHG emissions reduction (compared to conventional CNG) and production cost for different LCNG pathways

Based on these assumptions, low-level blending of hydrogen with conventional natural gas (Pathways 8-13) never leads to significant GHG emission reductions - these pathways have carbon intensities very similar to conventional CNG. In addition, the CA-GREET 2.0 carbon intensity for agricultural manure digestion for flared digesters (Pathway 3b) shows higher GHG emissions relative to conventional CNG. However, digesters with vented configurations (Pathway 3a) show very good GHG reduction potential, due to reduced methane emissions that would otherwise be vented into the atmosphere (note that this configuration is not widely adopted).

Five pathways show a GHG-reduction potential compared to CNG greater than $50 \%$ : three digester gas pathways (Pathways 1,2, and 3a), and the current and future pathways for woody and herbaceous biomass gasification followed by methanation (Pathways 4 and 5 ). ${ }^{5}$ Given these promising reductions in carbon intensity, we focus on these five low-GHG pathways in the remainder of this report. These pathways, including the conventional CNG baseline, will hereinafter in this report be referred to as follows:

- $\quad$ WWTP (1)

\footnotetext{
${ }^{4}$ For a discussion of hydrogen blending and natural gas, see Melaina et al. (2013).

${ }^{5}$ Note that Pathways 4 and 5 differ only in their estimated production cost and have identical emissions profiles.
} 
- Landfill gas (2)

- Ag. waste digester, vented (3a)

- Ag. residue gas. (4\&5)

- Urban wood waste gas. (4\&5)

- Woody forest biomass gas. (4\&5)

- CNG Baseline (14). 


\section{Feedstock Availability}

Pathways 4 and 5 rely on gasification of woody and herbaceous biomass. Projected biomass resource data, taken from the Billion Ton Update study for the year 2030 (DOE 2011), are used to determine the potential contribution of the these LCNG pathways selected in California and to quantify the availability and geographic distribution of the various feedstock types that may be used in each pathway. For this study we analyzed resources at all price points to determine the total resource potential for LCNG production. The resources considered include several woody and herbaceous feedstocks:

- Agricultural residues

○ Barley straw

○ Corn stover

○ Oat straw

○ Sorghum stubble

- Wheat straw

○ Annual energy crops

- Perennial grasses

- Urban wood waste

○ Wood waste from construction, repairing, remodeling, and demolition

- Wood components of municipal solid waste (MSW), such as packaging for durable goods, and yard trimmings

- Woody biomass-forests

○ Wood and bark residue from secondary milling operations

- Forest residues attributed to conversion of land to other uses

○ Conventional wood

○ Logging residues

$\bigcirc$ Forest thinning

○ Treatment thinning (residues from thinning in low-productivity forests).

Feedstock resources for anaerobic digestion biogas (Pathways 1, 2, and 3a) were also considered, even though data availability was limited. A recent study reports current resource potential (Murray et al. 2014), which was disaggregated on a per-county level for the purpose of this study (this resource estimation could be improved for future studies, in particular considering future projections). Three categories of anaerobic digestion gas are considered in this analysis:

- Waste water treatment plant sludge (WWTP)

- Landfill gas

- Agricultural waste (e.g., poultry, cattle, hog manure). 
Table 2 reports the resource potential of each of these feedstock types in California. Woody biomass from cellulosic sources and anaerobic digestion biogas from livestock manure are the largest resources, at about 30 trillion Btu/year (note that for livestock manure the share of vented vs. flared configuration is not available). Next are woody biomasses from forests and landfill anaerobic digestion gas, at about 20 trillion Btu/year, and anaerobic digestion biogas from WWTP sludge, at about 10 trillion Btu/year. Herbaceous biomass from agricultural residues provides the smallest resource at less than 1 trillion Btu/year. In addition to its low abundance, agricultural residue has relatively poor economics owing to its low energy density: commercial gasification and incineration processes typically avoid this feedstock in favor of woody feedstock, if available. In the future, purposely grown biomass (e.g., switchgrass) could represent a significant source of biomass for LCNG production.

\begin{tabular}{|c|c|}
\hline Resource & LCNG Potential (trillion Btu/year) \\
\hline Urban wood waste & 29.62 \\
\hline Agricultural waste & 28.74 \\
\hline Woody forest biomass & 21.23 \\
\hline Landfill gas & 20.85 \\
\hline WWTP & 10.91 \\
\hline Agricultural residue & 0.81 \\
\hline
\end{tabular}

Figure 3 maps the potential availability of each resource in California by county. Agricultural waste is the dominant resource in much of the agricultural-intensive Central Valley, whereas woody forest biomass is most abundant in Northern California and urban wood waste is the largest resource in much of Southern California. Landfill gas and WWTP sludge are also abundant near population centers, and the proximity to the final use point makes them, along with urban wood waste, particularly attractive resources for early applications. 


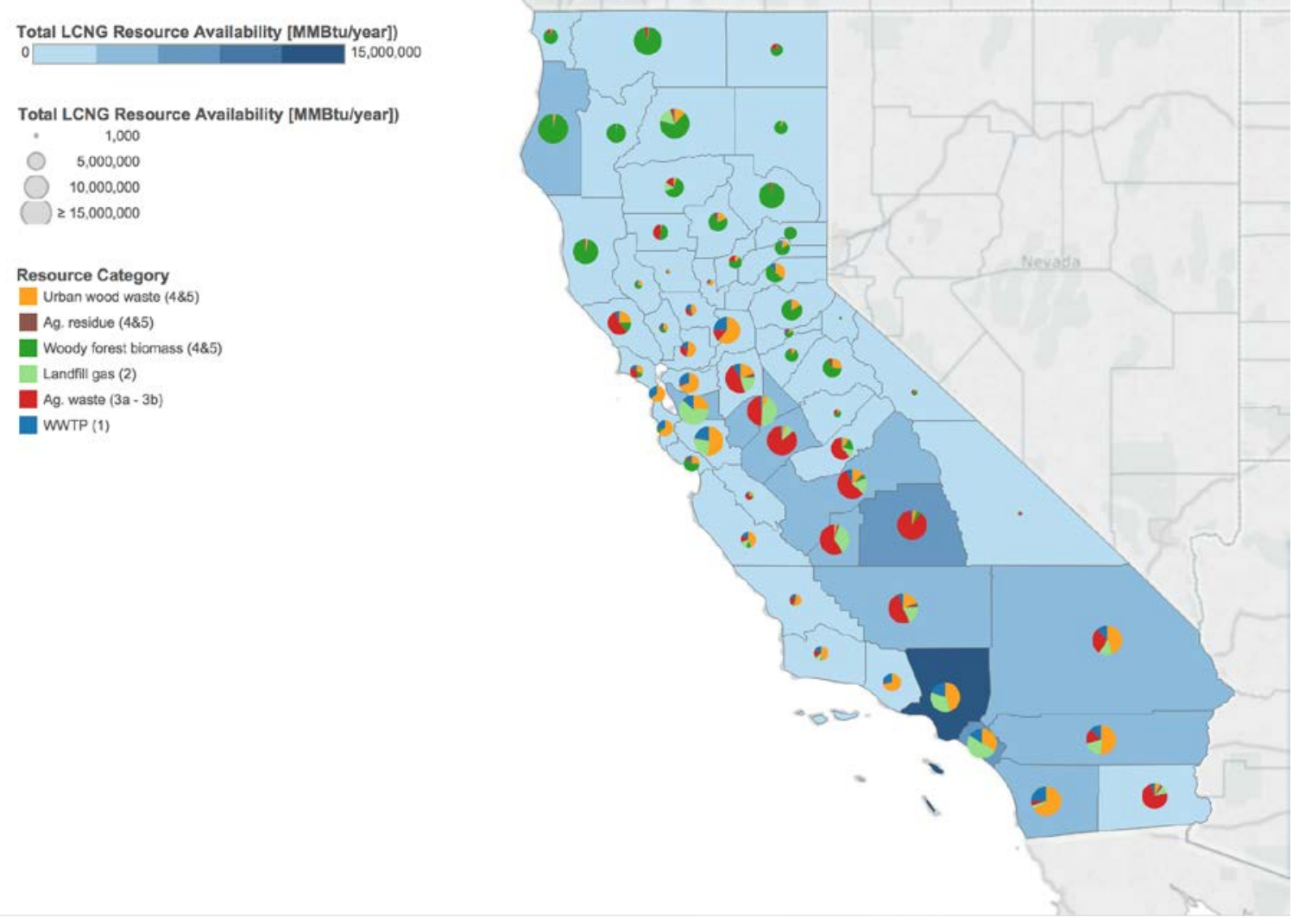

Figure 3. California's LCNG feedstock resources by county and feedstock type The shades of blue on the chart denote the total availability potential of LCNG for each county. 


\section{Projected Transportation Fuel Demand Analysis}

Four vehicle classes are considered to determine the potential demand for compressed natural gas $(\mathrm{CNG})$ for use in transportation applications: light-duty vehicles (LDVs), medium-duty vehicles (MDVs), heavy-duty vehicles (HDVs), and buses. We drew our estimate of natural-gasvehicle sales potential in California from a recent report prepared by E3 (2014) and used a spatially detailed vehicle stock model to project CNGV fuel demand in 2030 (the Scenario Evaluation and Regionalization Analysis model (SERA) (Melaina 2015). The SERA model disaggregates the projection from E3 (2014) to a per-county fuel demand based on vehicle age ${ }^{6}$ and fuel economy. Table 3 shows the resulting projected CNGV vehicle stock, vehicle miles traveled (VMT), efficiency, and consumption in 2030 as predicted by the modeling adopted in this report. LDVs constitute about two-thirds of the total 1.9 million CNGVs on the road in California by 2030, but account for only about one third of annual fuel consumption. Conversely, MDVs and HDVs - which are driven more than LDVs and have much higher fuel consumption - constitute about one-third of total CNGVs but are responsible for about twothirds of the total fuel consumption.

Table 3. Projected California CNG Vehicles Stock, Miles Traveled, Fuel Efficiency, and Consumption in 2030

\begin{tabular}{|lccccccc|}
\multicolumn{1}{c}{$\begin{array}{c}\text { CNG Vehicle } \\
\text { Category }\end{array}$} & $\begin{array}{c}\text { CNG } \\
\text { Vehicles } \\
\text { on the } \\
\text { Road }\end{array}$ & $\begin{array}{c}\text { VMT } \\
\text { (miles } \\
\text { /day) }\end{array}$ & $\begin{array}{c}\text { VMT } \\
\text { (million } \\
\text { miles/y) }\end{array}$ & $\begin{array}{c}\text { Fuel } \\
\text { Efficiency } \\
\text { (miles/gge) }\end{array}$ & $\begin{array}{c}\text { Fuel } \\
\text { Consumption } \\
\text { (gge/y) }\end{array}$ & $\begin{array}{c}\text { Share of } \\
\text { CNG } \\
\text { Vehicles }\end{array}$ & $\begin{array}{c}\text { Share } \\
\text { of } \\
\text { Fuel }\end{array}$ \\
\hline Buses & 35,000 & 33.65 & 400 & 13.2 & $32,000,000$ & $1.8 \%$ & $2.8 \%$ \\
\hline $\begin{array}{l}\text { Heavy duty } \\
\text { vehicles (HDV) }\end{array}$ & 91,000 & 36.95 & 1,200 & 6.3 & $194,000,000$ & $4.6 \%$ & $17 \%$ \\
\hline $\begin{array}{l}\text { Medium duty } \\
\text { vehicles (MDV) }\end{array}$ & 547,000 & 37.04 & 7,400 & 13.4 & $554,000,000$ & $28 \%$ & $48 \%$ \\
\hline $\begin{array}{l}\text { Light duty } \\
\text { vehicles (LDV) }\end{array}$ & $1,310,000$ & 31.45 & 15,000 & 39.9 & $377,000,000$ & $66 \%$ & $33 \%$ \\
\hline
\end{tabular}

Figure 4 shows the distribution of projected CNG consumption by county and vehicle type, which is well correlated with population density (not shown in Figure 4).

\footnotetext{
${ }^{6}$ Since vehicles tend to be driven less as they age.
} 

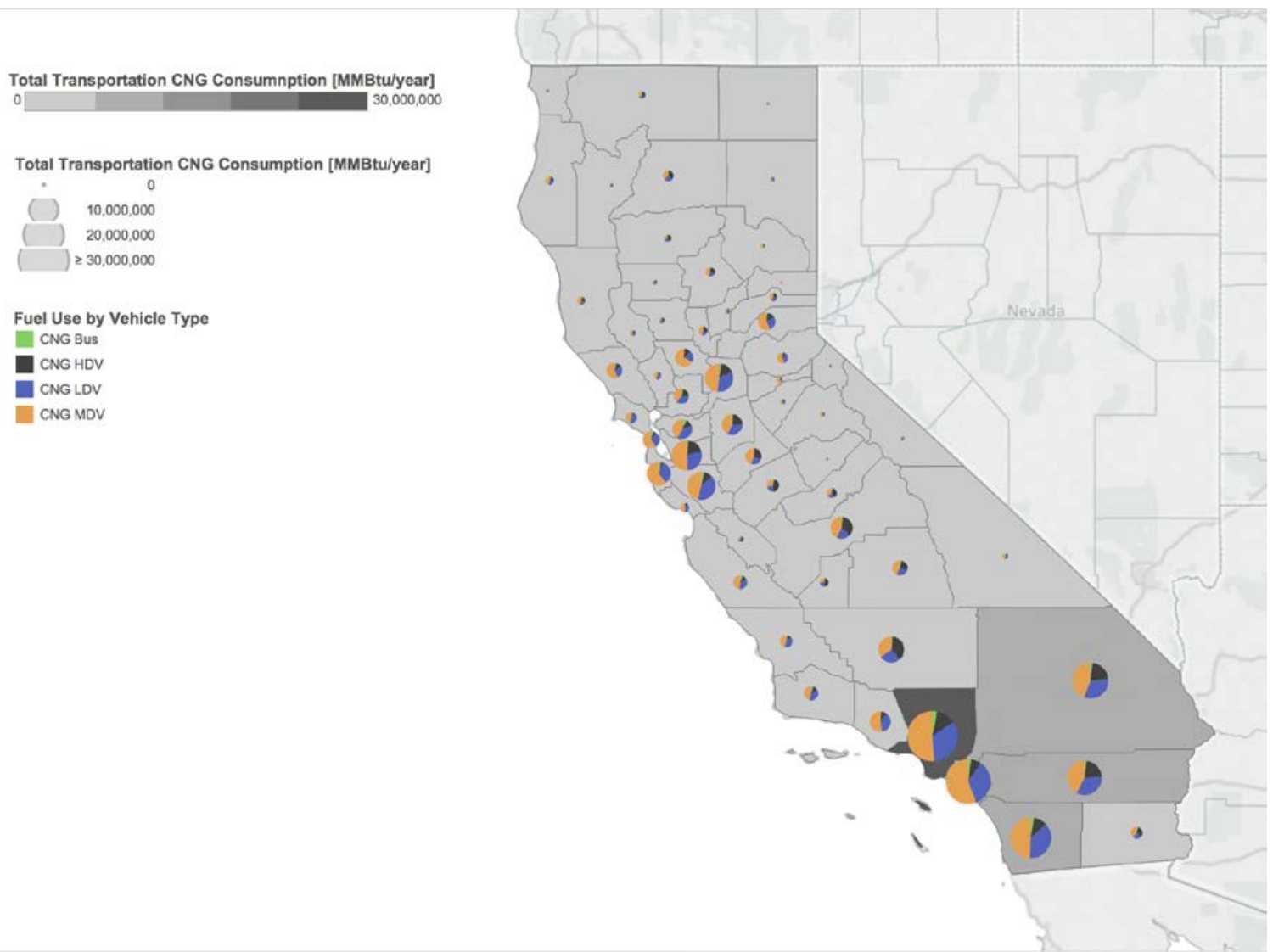

Figure 4. Projected natural gas consumption for transportation applications in 2030 by county and vehicle type

The shading of the underlying map denotes the relative fuel demand for each county.

A comparison of the potential for LCNG production in California to the quantity of demand projected by E3 (2014) is shown in Figure 5. While demand appears to be higher than supply availability identified in this study, as additional pathways for LCNG are developed in the future, it may be possible to provide sufficient LCNG to match the demand quantified in the E3 (2014) report with regional production. Import of LCNG from other regions outside of California, while not considered in this report, might also be a valuable and low-cost solution to match the high demand for low-carbon fuels in California. 


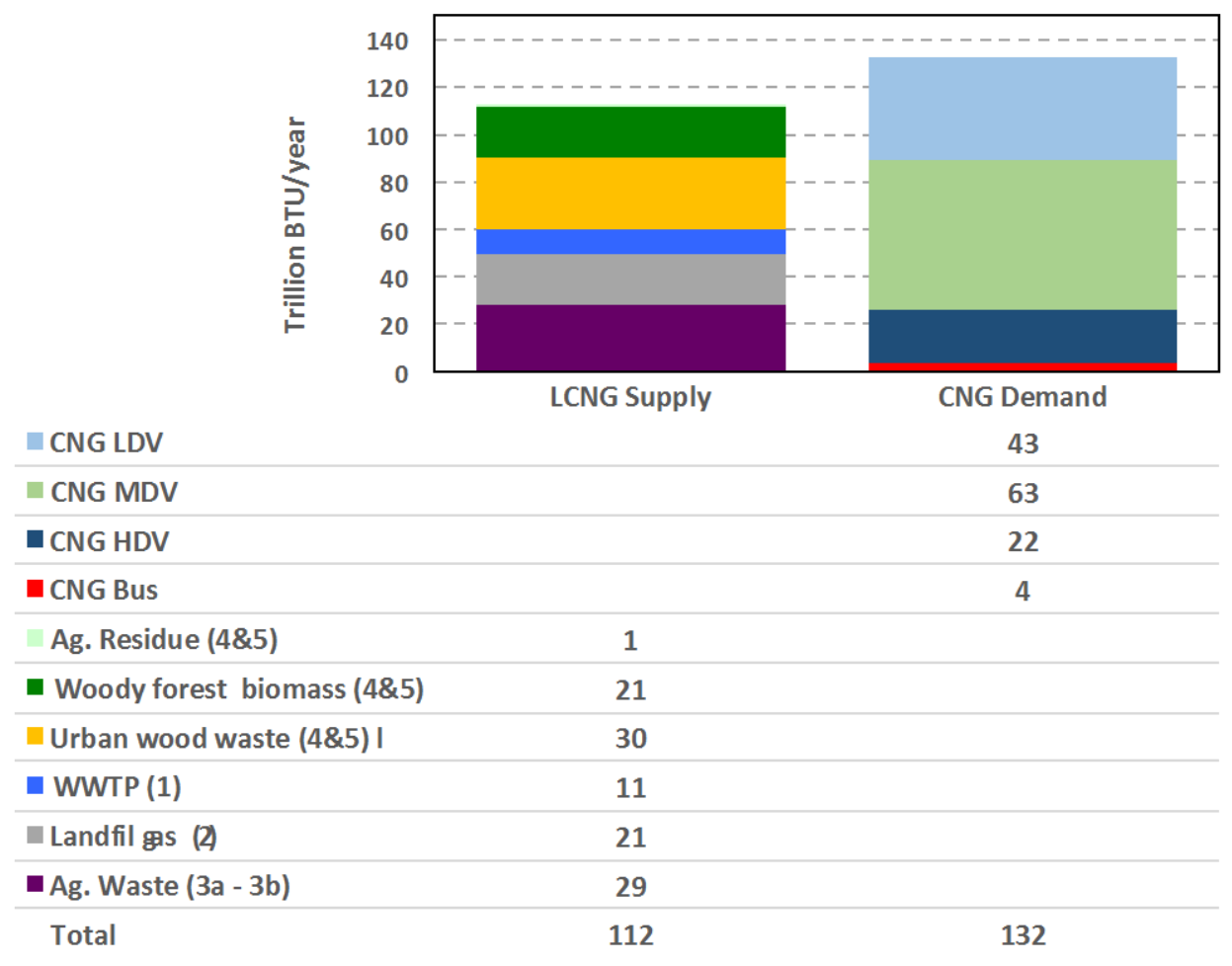

Figure 5. Potential LCNG supply and CNG demand for transportation applications in California

California shows significant heterogeneities in terms of geography and demographics. The northern part of the state has significantly greater availability of LCNG feedstock resources, while the market demand for transportation fuels in significantly higher in Southern California, due higher population density. This discrepancy is illustrated in Figure 6, where pie chart sizes indicate the magnitude and proportion of LCNG supply (green) and demand (red), and the shading of counties indicates the relative shortfall or surplus in supply in each county. 

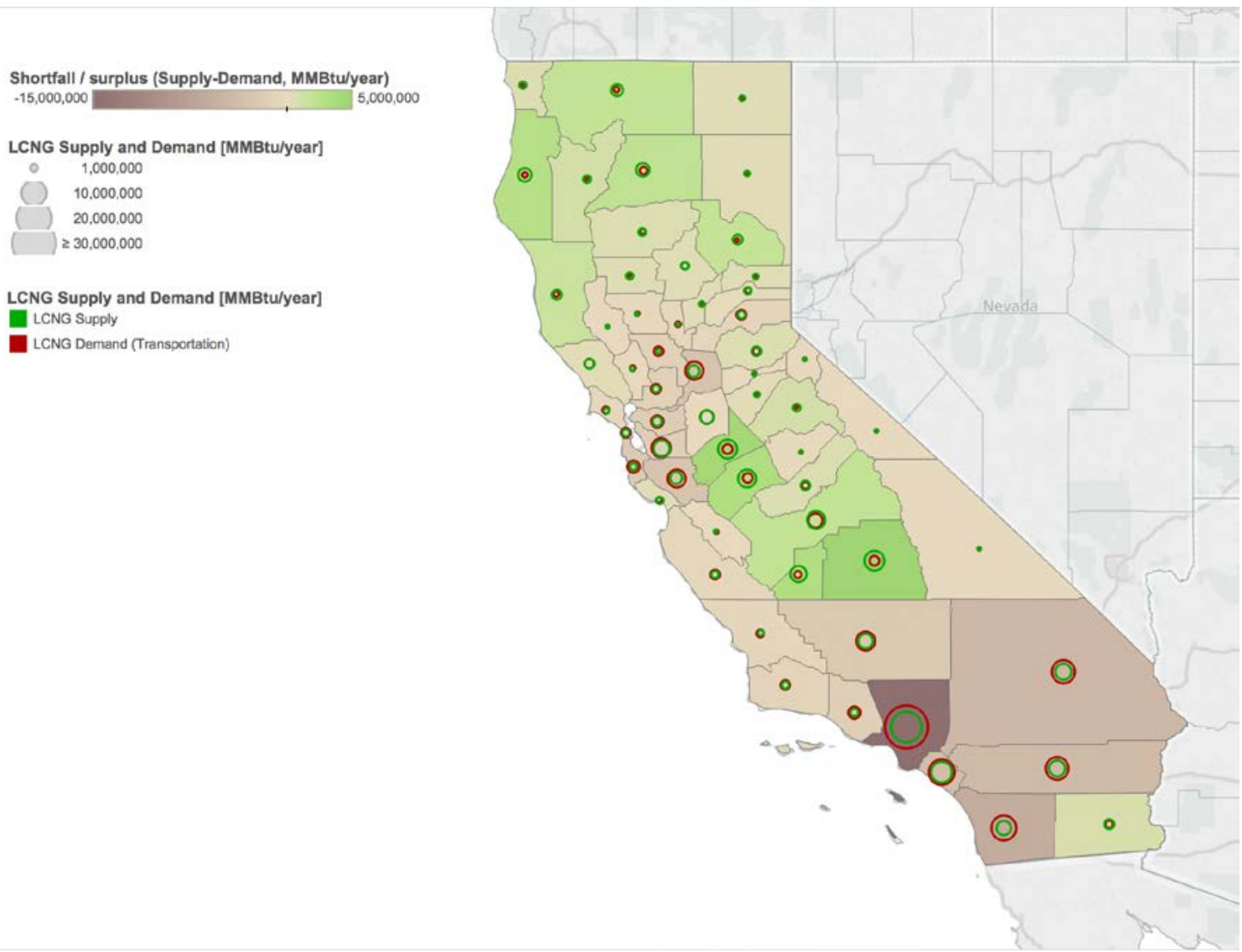

Figure 6. Supply and demand for LCNG transportation applications in California by county

Demand is determined by the sum of all vehicle categories considered, and LCNG supply reflects the five high-GHG emissions-reduction pathways identified (Pathways 1, 2, 3a, 4, and 5).

Considerations on likely early adopters for LCNG are also important. MDV, HDV, and bus fleets appear to be good options for LCNG use, since such fleets are typically operated from central hubs and have relatively high annual vehicle miles traveled. Moreover, investments in $\mathrm{CNG}$ infrastructure for one or more fleets can benefit from predictable utilization rates. Fleets tend to maximize utilization rates and lower investment risk for fleet fueling infrastructure compared to public retail stations relying primarily on less predictable LDV demand. Economies of scale offer additional advantages for fleet applications. Lastly, fleet fueling infrastructure may not require fast fueling capability, which could lower the infrastructure cost even further. Existing CNG fueling infrastructure supporting long-distance HDVs also offers early market opportunities for LCNG. Determining the relative economic effectiveness of this infrastructure development approach would require additional analysis. For the present analysis, infrastructure requirements are determined on a capacity and demand basis, with sufficient allocation of refueling station capacity determined as a function of total projected fleet demand.

Markets for LCNG would take time to fully develop, and as with any resource-constrained system, it is likely that lowest-cost resources would be developed first. As demand continues to grow, subsequent tiers of higher-cost resources would be developed. Initially, investors would look for the lowest-cost pathways for producing LCNG and the highest price that can be served by the business. In Southern California, the demand for fuel is high, as is the pressure for 
improving air quality and reducing GHG emissions. Businesses operating vehicles in this area are being encouraged to reduce their emissions and may have more incentives to secure clean fuels. Based upon the analysis results shown in Figure 6, Southern California has a long-term projected shortfall in LCNG supply, though it does have substantial local resources. While transport of natural gas is relatively inexpensive due to a well-established pipeline infrastructure, some supply-chain costs could be reduced by utilizing resources close to the demand point. Thus, it is likely that near-term CNG infrastructure projects could accommodate LCNG produced within the same county, especially with systems relying on truck delivery. However, as local supplies are depleted, farther (and more expensive) resources may be exploited. Figure 7 shows the long-term discrepancy between counties with surplus or shortfall of supplies, indicated by the area of the rings superimposed over each county. The balance of this surplus and shortfall is identical, in aggregate, to the stacked bar charts shown in Figure 5. Counties with demand greater than their supply of LCNG are considered to have a shortfall of resources, indicated by red rings in Figure 7. Green rings denote counties with potential surplus for LCNG. As discussed above, in a fully developed market and at scale, an extensive LCNG supply network would likely require some long distance transport of the fuel when less expensive local resources have been fully developed. As such, large volumes of LCNG may eventually be transported from counties with significant surplus to counties with significant shortfall. Identifying an economically efficient transition for the deployment of such a network, however, would require additional analysis.

Several aspects ease the issues related to geographical discrepancies between supply demand: (1) distribution infrastructure for natural gas already exists and is well developed in California; (2) while this analysis focuses on use of LCNG for transportation, many other uses can be envisioned that would utilize surpluses locally; and (3) policies allowing trade of LCNG certificates can enable regions with excess supply to sell LCNG credits to regions with shortfalls. The surplus LCNG can then be used for other local purposes. Such a credit system would alleviate costs associated with dedicated long-distance movement of LCNG. Finally, while California has a demand advantage (due to low-carbon and clean air policies), other locations may have lower supply costs. This study focuses on the California market only; however, LCNG production outside California could provide low-cost LCNG and ease supply chain issues. 


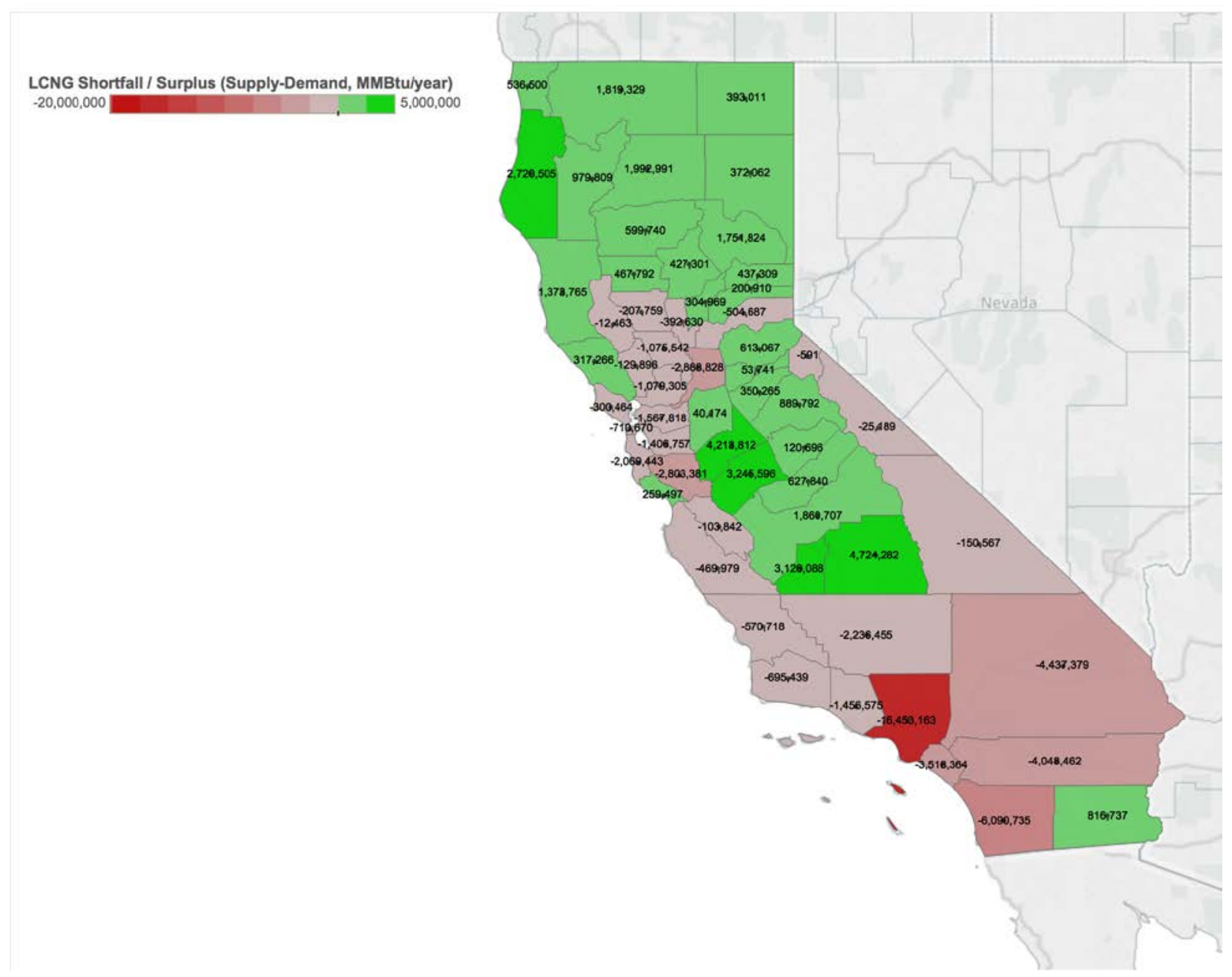

Figure 7. Supply and demand for LCNG

Red denotes LCNG supply shortfall and green denotes LCNG supply surplus. 


\section{Well-to-Wheels Emissions}

Well-to-wheels (WTW) emissions are an indicator of a vehicle's cumulative emissions on a permile-traveled basis, including emissions attributed to fuel production, processing, and distribution (well-to-tank, WTT) as well as emissions from vehicle operation or tailpipe emissions (tank-to-wheels, TTW). WTW studies have been proposed both to assess different fuel pathways (Wang 1996; Brinkman et al. 2005; Edwards, Larive, and Beziat 2011; Waller et al. 2014), including CNG, and to compare the same pathways in different scenarios and regions (Orsi et al. 2016).

This section reports a detailed WTW comparative analysis, based on the CA-GREET 2.0 model (CARB 2016), focusing on the five LCNG pathways identified that allow for significant GHG emission reductions compared to conventional CNG. Figure 8 shows the well-to-tank GHG emissions of these selected LCNG pathways compared with conventional fossil CNG, on a grams per-gge energy basis. $^{7}$

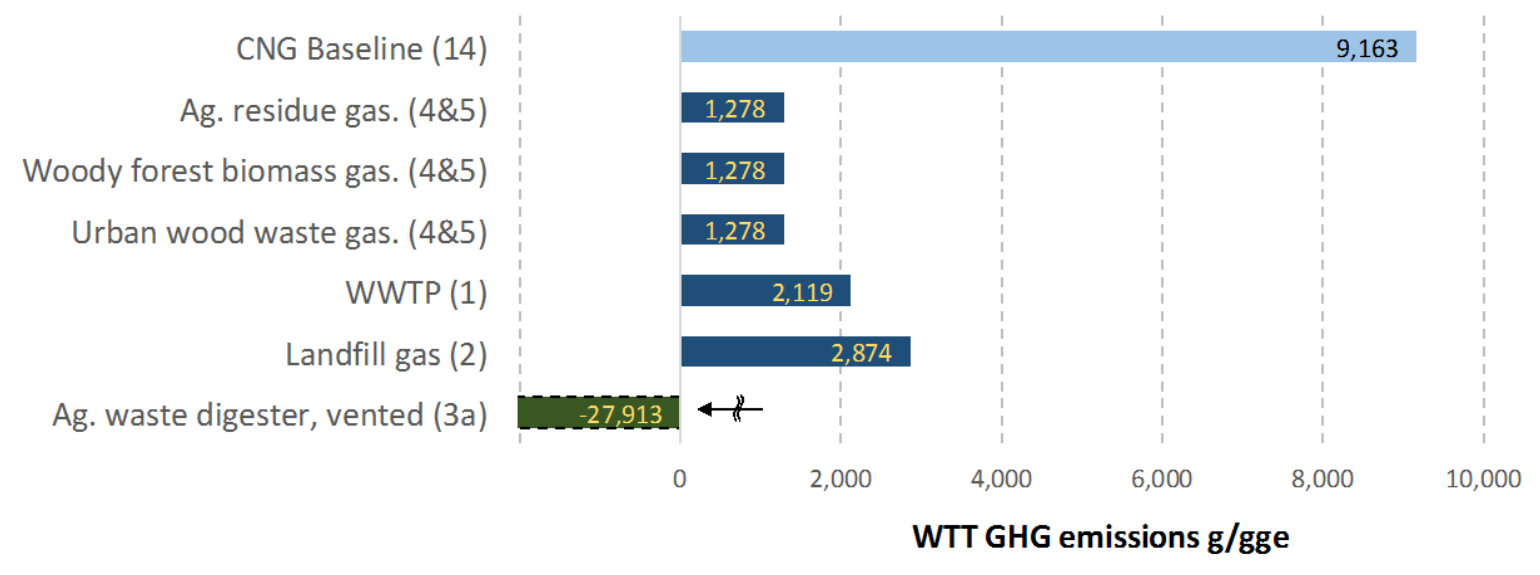

Figure 8. Well-to-tank GHG emissions of conventional CNG and selected LCNG pathways

\footnotetext{
${ }^{7}$ Gasification pathways shown in Figure 8 use detailed process analysis for the Fischer-Tropsch pathway as a surrogate (the difference between producing LCNG via gasification and methanation or producing synthetic diesel via Fischer-Tropsch is only the last unit operation, which is closely analogous in terms of GHG contribution).
} 
Figure 9 shows the comparison of WTW emissions (in grams of GHGs per mile driven) for each vehicle class, reflecting fuel economy differences between vehicle classes.

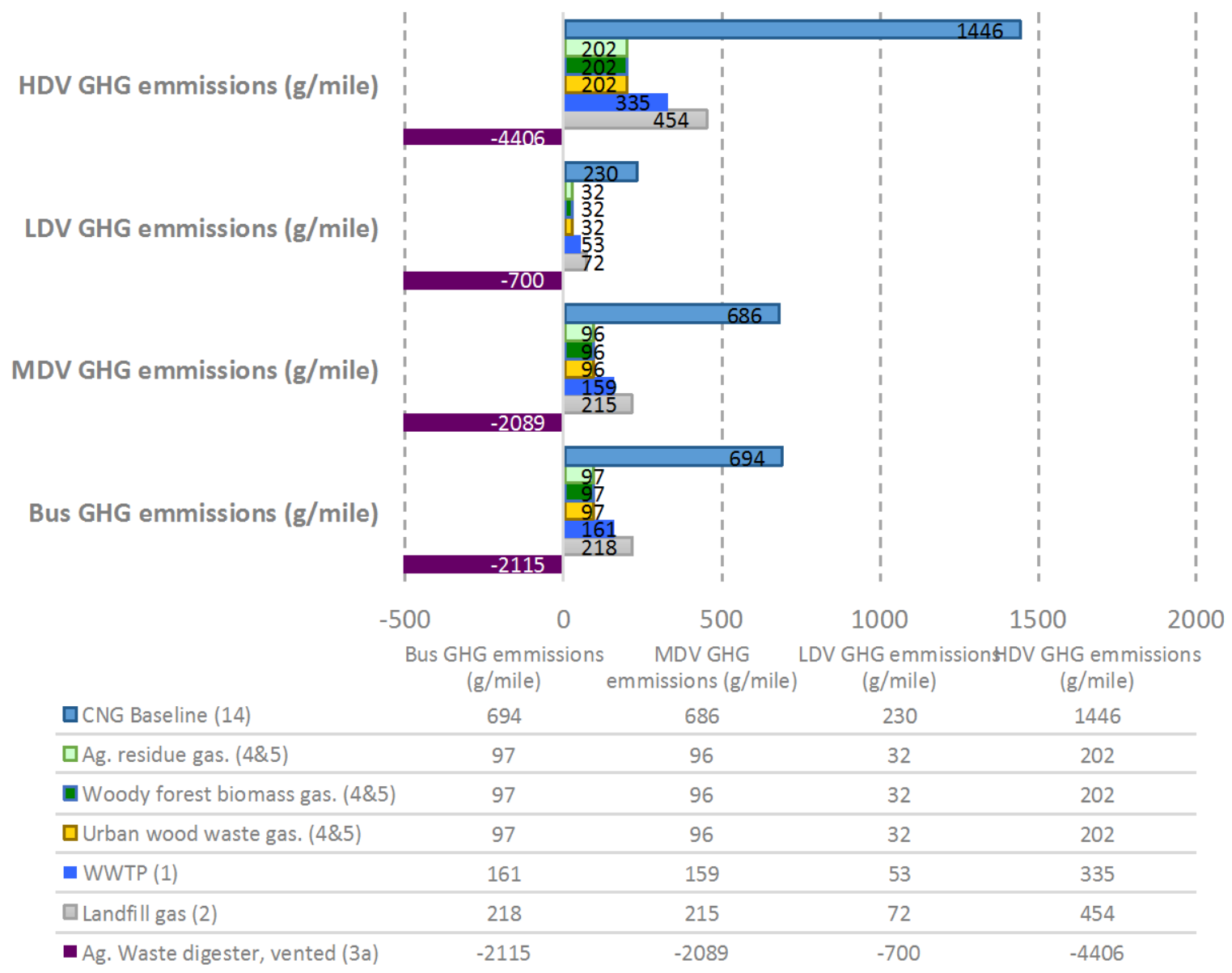

Figure 9. Well-to-wheels GHG emissions of conventional and low-carbon fuel pathways for various transportation applications

Note: Fuel efficiency assumptions are listed in Table 3.

Figure 10 compares the WTW GHG emissions for MDV applications with the corresponding feedstock availability for each low-carbon pathway, illustrating the tradeoff between a feedstock's effectiveness in reducing GHG emissions and its availability in California. For comparison, CNG MDVs emit approximately $686 \mathrm{~g} / \mathrm{mile}$. While resource availability of agricultural waste in California is estimated at about 29 trillion Btu per year, the share of digesters with vented exhaust (Pathway 3a) vs. flared emissions (Pathway 3b) is not known. 
Therefore, Pathway $3 \mathrm{a}$ is not listed in Figure 10 and agricultural waste or livestock manure anaerobic digestion (Pathways $3 \mathrm{a}$ and $3 \mathrm{~b}$ ) is not further considered in this report. ${ }^{8}$

Results from Figure 10 show that urban wood waste gasification/methanation is the lowestemitting pathway and has the largest resource availability. Woody forest waste and landfill gas also have large availability in California and show significantly lower emissions compared to CNG vehicles using fossil natural gas.

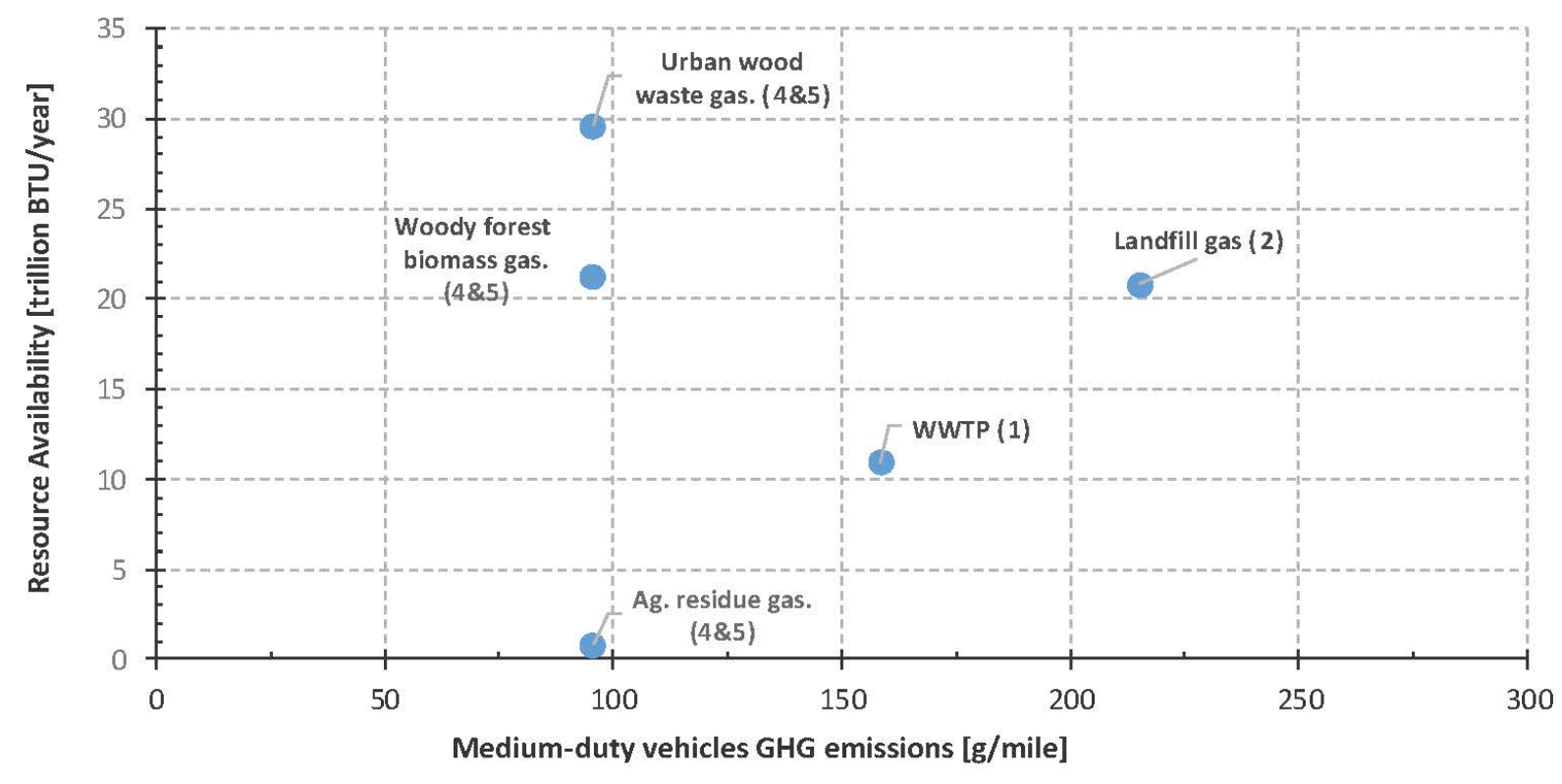

Figure 10. Abundance and well-to-wheels GHG emissions of selected LCNG pathways for different resource types in California

In Southern California in particular, where demand for LCNG is high, the abundance of urban wood waste could make it an especially favorable feedstock given its good GHG reduction potential and high availability that could provide economies of scale to yield favorable economics. Southern California also has significant landfill and WWTP resources. Overall, issues related to geographic distance between supply and demand for each resource are mitigated for all the pathways by pipeline injection of LCNG into the existing natural gas infrastructure.

\footnotetext{
${ }^{8}$ Pathway $3 \mathrm{~b}$ (Agricultural waste digester, flared) shows GHG emissions that are higher than the CNG baseline in CA-GREET, and while Pathway 3a (Agricultural waste digester, vented) would allow for significant GHG emission reductions compared to the CNG baseline - due to capturing and using methane previously vented - the current use of vented digesters in California is not known and flaring of methane or utilization for heating or other purposes are considered more common for large agricultural waste treatment facilities.
} 


\section{Economic Analysis}

A detailed economic analysis, performed using the H2A discounted cash flow model (DOE 2015), is proposed to calculate the total cost for each LCNG pathway. H2A is based on inputs including installation, operations and maintenance, and capital cost as well as cost of feedstock, including feedstock transportation costs. The resulting cost estimate therefore reflects full market development. Costs for biogas resource (landfill gas, agricultural waste, WWTP sludge) and woody biomass collection and cleanup are derived from DOE (2011). Capital cost estimates for gasification and methanation are taken from Apt et al. (2008). Retail station costs are estimated based on stations funded by the American Recovery and Reinvestment Act. These costs are similar to those published by Clean Cities (Smith and Gonzales 2014). The following financial assumptions have been used for the discounted cash flow analysis:

- $10 \%$ real, after-tax discount rate (H2A baseline)

- Production: debt/equity ratio $=0(\mathrm{H} 2 \mathrm{~A}$ baseline $)$

- Retail dispensing: debt/equity ratio $=0.5$

- Feedstock costs: weighted-average cost of full resource utilization

- Commodities cost (e.g., electricity): Energy Information Administration projections.

We do not include additional costs for distribution infrastructure: costs are calculated up to a pipeline injection. Figure 11 shows the production cost of the selected LCNG pathways. These costs include production and gas clean-up to meet pipeline quality specifications but are not directly comparable to retail price: additional fuel mark-up is necessary to accommodate expense recovery of retail capital and operating costs. The weighted-average production cost, based on feedstock availability, for all the LCNG resources is $\$ 1.27 /$ gge.

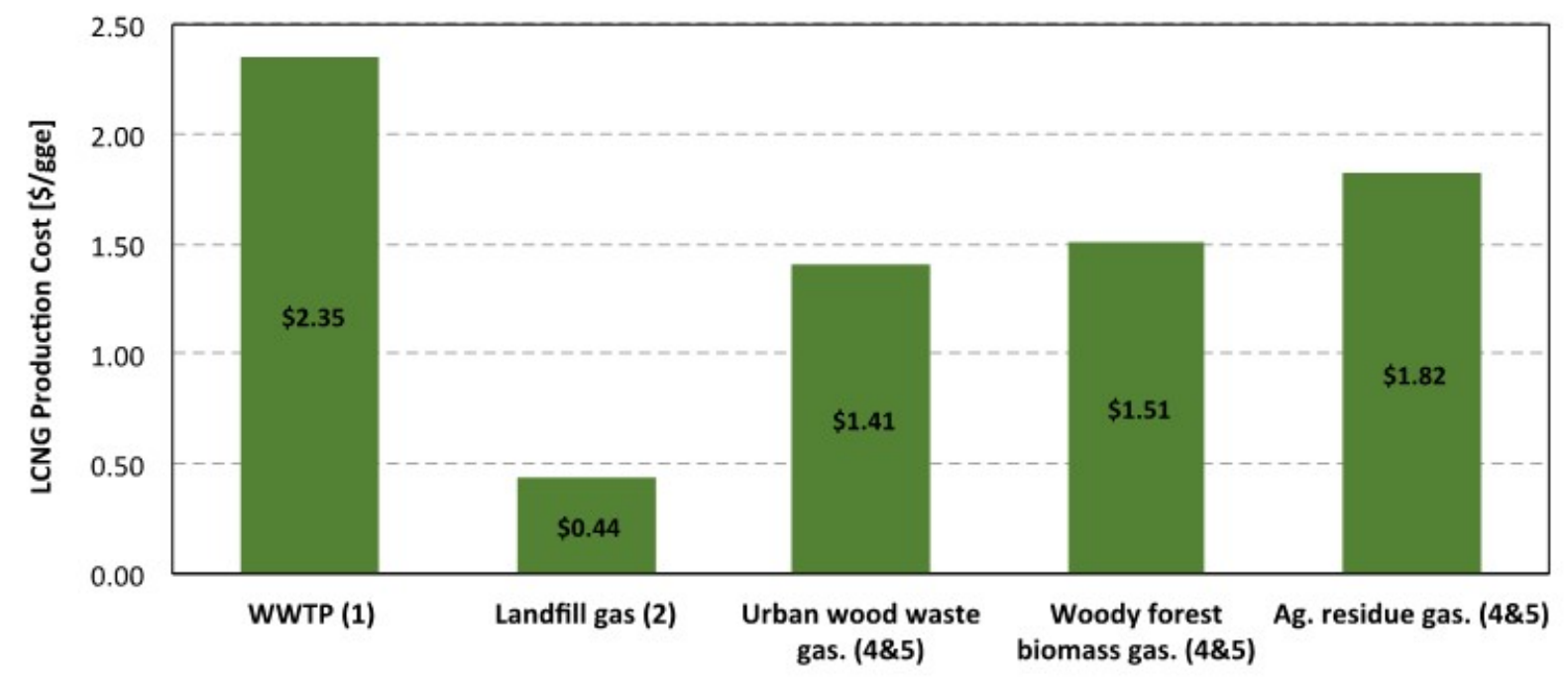

Figure 11. Production cost of selected LCNG pathways

The MFAST model (Multiple Fuel Financial Analysis Scenario Tool), an internal NREL tool based on the publically available H2FAST model (NREL 2016), is used to calculate retail prices for LCNG. MFAST estimates a levelized financial cost of a retail refueling station based on its 
construction, financing, and operation expenses. Operation expenses are computed based on different levels of demand. The model determines a break-even retail price of fuel on a per-gge basis such that all costs are covered and equity investors would achieve a return. For this analysis, we assume an internal rate of return of $10 \%$ on an after-tax basis to determine the final retail price. Table 4 reports costs and operating characteristics for a retail LCNG refueling station.

Table 4. LCNG Retail Refueling Station Characteristics

\begin{tabular}{|lll|}
\hline Station capacity & $70,000 \mathrm{gge} / \mathrm{month}$ & $30,000 \mathrm{gge} / \mathrm{month}$ \\
\hline Capital cost & $\$ 1.00$ million & $\$ 0.50$ million \\
\hline Installation cost & $\$ 0.30$ million & $\$ 0.15$ million \\
\hline Operations and maintenance & $\$ 0.07$ million/year & $\$ 0.04$ million/year \\
\hline Market Share & $20 \%$ of all stations & $80 \%$ of all stations \\
\hline Fuel dispensed & $37 \%$ of all fuel & $63 \%$ of all fuel \\
\hline Break-even price of dispensed fuel & $\$ 2.27 / \mathrm{gge}$ & $\$ 2.36 / \mathrm{gge}$ \\
\hline Retail margin (revenue minus fuel cost) & $\$ 1.09 / \mathrm{gge}$ & $\$ 1.00 / \mathrm{gge}$ \\
\hline
\end{tabular}

For a larger station (i.e., 70,000 gge/month), the retail price required to cover those expenses and guarantee a $10 \%$ return rate to the investors is $\$ 2.27 /$ gge. For smaller stations (i.e., 30,000 gge/month) a higher retail price of $\$ 2.36$ is required. Large stations might serve HDV and some MDV demands, while small stations would tend to serve MDV and LDV demands. To calculate an average retail price for LCNG we assumed that small stations account for $80 \%$ of the total station count, leading to a weighted average $\$ 2.30$ for LCNG retail sale price (an average retail margin of $\$ 1.05 / \mathrm{gge})$.

Figure 12 reports a breakdown of levelized costs for the two station types considered, as well as the retail price of fuel ("Sales revenue" in Figure 12) determined by MFAST to guarantee a 10\% return rate based on a 20 -year operating life. In analyzing retail station financial performance, we assume that LCNG delivered to the stations reflects a volume-weighted cost across all pathways of $\$ 1.27 / \mathrm{gge}$, which is the major cost component driving the total retail sale price of transportation LCNG for transportation applications. 
Levelized value performance for 70,000gge/month station

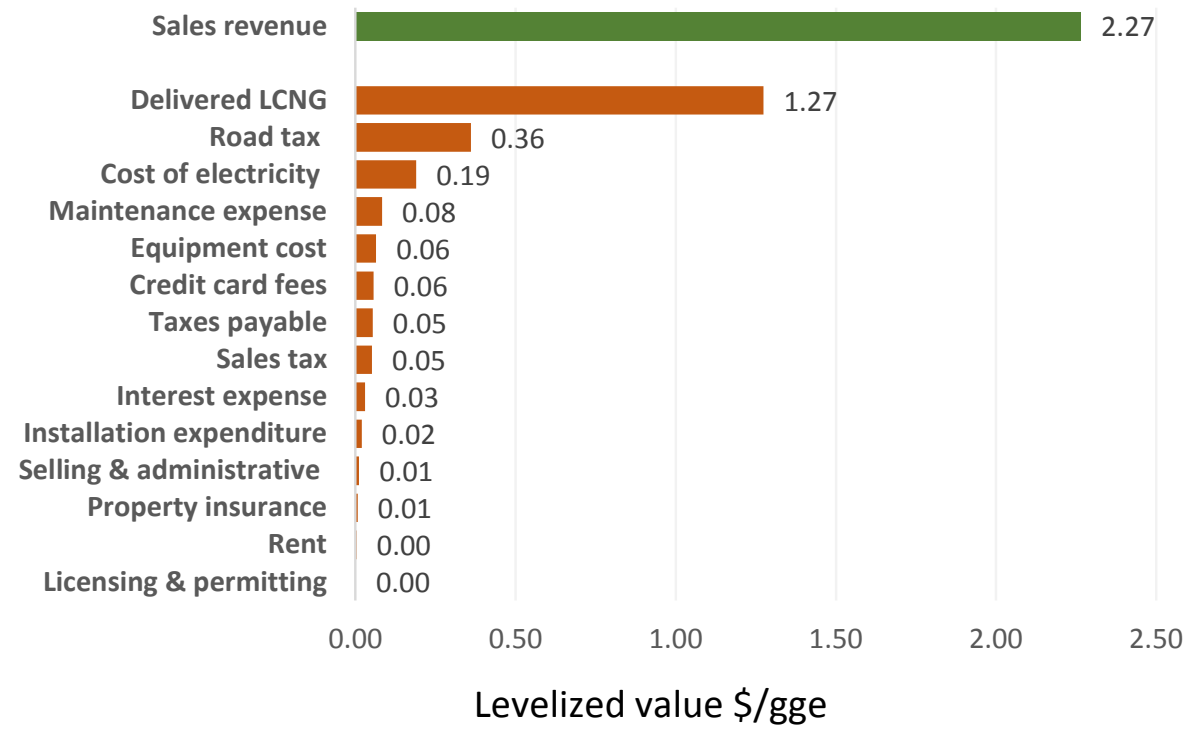

Levelized value performance for $30,000 \mathrm{gge} /$ month station

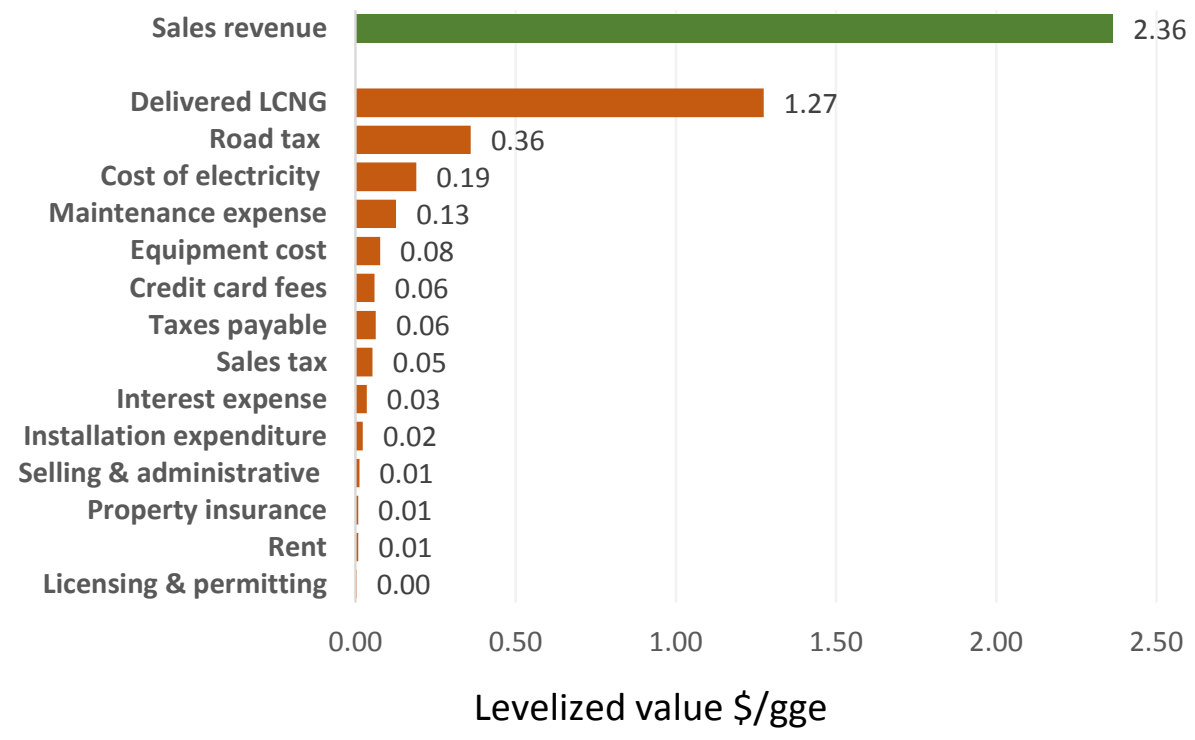

Figure 12. Levelized financial analysis for $70,000 \mathrm{gge} / \mathrm{month}$ LCNG stations (top) and 30,000 gge/month LCNG stations (bottom)

Note: The difference between the green bar and the sum of the orange bars is the net profit.

Figure 13 provides a breakdown of the total retail sale price of the selected LCNG pathways considering the specific LCNG production cost estimates as well as a retail margin of $\$ 1.05 /$ gge and a carbon tax of $\$ 50 /$ ton $\mathrm{CO}_{2}$, assumed to mimic policies such as California's Low Carbon Fuel Standard. Under these assumptions, the landfill gas pathway (2) is the lowest-dispensedcost LCNG fuel in this analysis, which also provides almost 70\% emissions reductions compared to conventional CNG. Urban wood waste and woody forest biomass gasification (4\&5) also show relatively low cost, while guaranteeing large availability in California and good GHG emission reductions compared to fossil $\mathrm{CNG}$ and petroleum-derived fuels. 


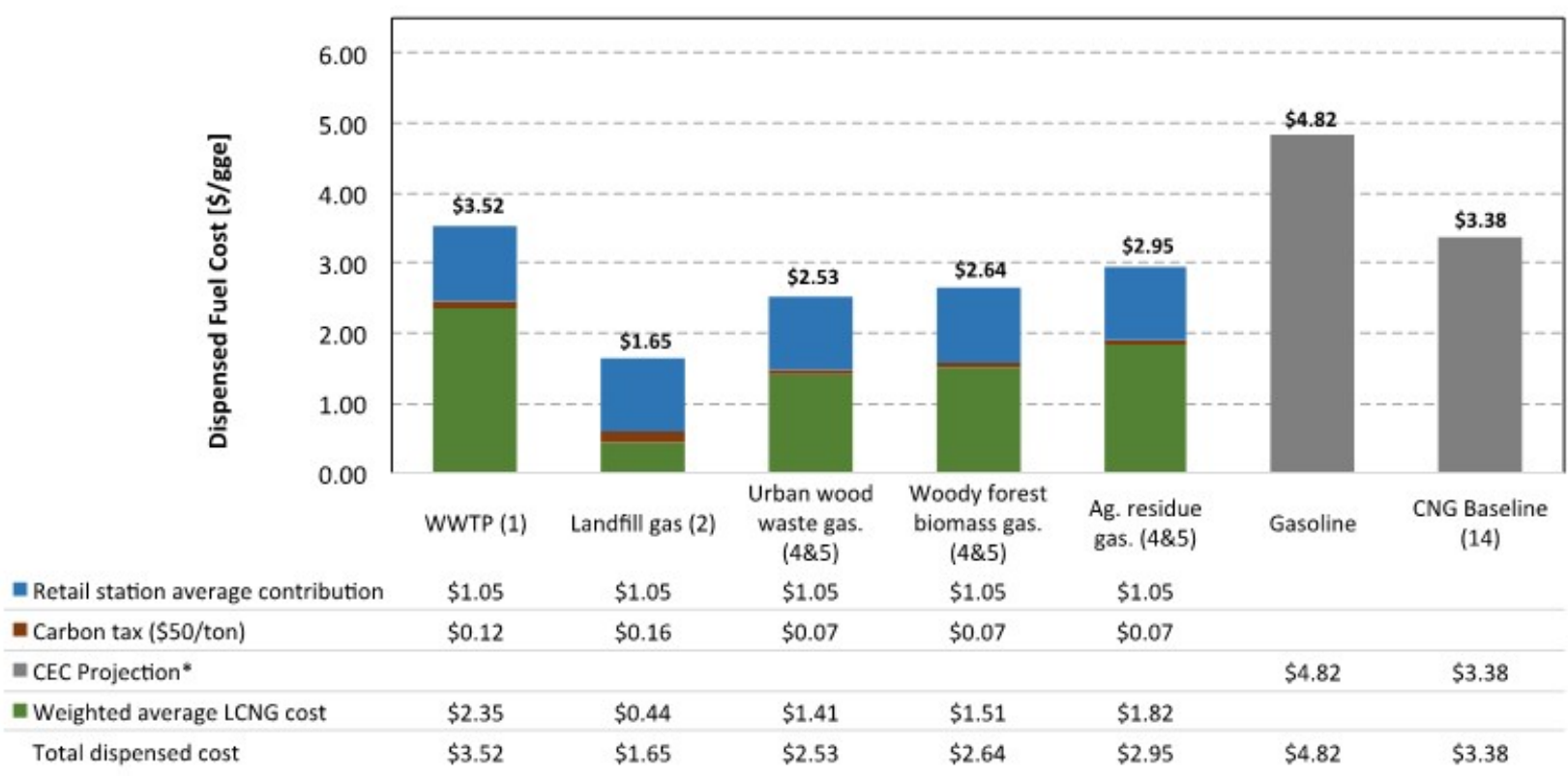

Figure 13. Breakdown of total LCNG retail sale price for selected pathways

*Projection is based on extrapolation from data used in a staff report by the California Energy Commission (Bahreinian et al. 2016; van der Werf 2016). Note that the gasoline and CNG baseline prices include forecasts for the California price of carbon per metric ton under the existing California cap-andtrade regulation.

Given its role in reducing emissions from transportation and highly concentrated demand, Southern California can be expected to play an early role in LCNG adoption. Landfill gas shows the lowest cost and is one of the more abundant potential resources in Southern California, with a potential of over 20 trillion Btu per year, indicating significant potential for adoption of low-cost and domestic LCNG that significantly reduce the carbon footprint of transportation. Urban wood waste gasification followed by methanation (Pathway 4), which offers the highest GHG emission reduction potential, also shows a relatively low cost and significant availability in Southern California. Other LCNG pathways have a limited availability in this part of the State, and WWTP (Pathway 1), while largely available, shows significantly higher cost estimates. Table 5 summarizes the extent of infrastructure that would support the retail dispensing of LCNG in California for a total of about 1 billion gge/year, including financial analysis of the investment required to support such infrastructure.

Table 5. Summary of Retail Infrastructure Costs

\begin{tabular}{|llll|}
\hline Station capacity & $70,000 \mathrm{gge} / \mathrm{month}$ & $30,000 \mathrm{gge} / \mathrm{month}$ & Total \\
\hline Abundance (\% of stations) & $20 \%$ & $80 \%$ & \\
\hline Number of stations & 303 & 1,209 & 1,512 \\
\hline $\begin{array}{l}\text { Equipment and installation cost } \\
\text { (thousands \$ per station) }\end{array}$ & $\$ 1,316$ & $\$ 668$ & \\
\hline $\begin{array}{l}\text { Equipment and installation cost } \\
\text { (thousands \$ total) }\end{array}$ & $\$ 398,677$ & $\$ 807,651$ & $\$ 1,206,328$ \\
\hline
\end{tabular}




\section{Summary}

A variety of LCNG pathways have been examined for a California case study with respect to life-cycle GHG emissions, resource availability, demand potential from the transportation sector, and fuel supply economics. To significantly reduce the carbon intensity of natural gas supply, five key pathways to produce LCNG are identified that offer significant GHG emission reductions compared to conventional compressed natural gas from fossil fuels, based on an updated version of the GREET model developed for California. These pathways include: anaerobic digestion biogas upgraded to pipeline quality gas sourced from (1) WWTP sludge, (2) landfill gas, and (3) agricultural waste (in a process that is vented, not flared); and gasification followed by methanation of woody or herbaceous biomass, including agricultural residue, urban wood waste, and woody forest biomass. These pathways assume direct injection of the produced LCNG into the existing natural gas distribution infrastructure, while all pathways involving lowpercentage blending of LCNG or hydrogen with fossil natural gas do not achieve significant GHG emission reductions.

Urban wood waste and agricultural waste have a significant resource potential in California, each on the order of 29 trillion Btu per year. Resource potential for woody forest biomass and landfill gas are lower at nearly 21 trillion Btu per year, whereas agricultural residues are much lower at less than 1.0 trillion Btu per year. These resources are distributed heterogeneously across the state, with woody forest biomass predominantly in the north, agricultural waste in the Central Valley, and WWTP, landfill gas, and urban wood waste near large urban centers (Los Angeles and the Bay Area).

A demand scenario for compressed natural gas vehicles developed by E3 (2014) is adopted as a reference for potential future market demand from buses, LDVs, MDVs, and HDVs. Total potential demand from this scenario in 2030 is estimated at 132 trillion Btu per year, which is only slightly greater than the LCNG supply potential identified (112 trillion Btu per year). In comparing demand and LCNG production potential, urban centers have a significant local resource potential but would eventually have to draw from more distant resources in the Central Valley and Northern California in a fully developed market.

An economic analysis, considering both LCNG production costs and detailed retail station construction and operation costs, is proposed to evaluate the competitiveness of the different LCNG pathways identified. Retail station capital costs are shown to be a significant fraction of total costs, while feedstock costs (driving LCNG production costs) are taken from previous studies. Under these assumptions, fully developed supply networks could provide LCNG at competitive retail prices - in most cases under $\$ 3.00 /$ gge (the exception being LCNG from WWTP), which compares favorably with fossil-based conventional CNG at \$3.38/gge. The anaerobic digestion of organic material in landfills (landfill gas, Pathway 2) is identified as the least-cost pathway among those analyzed, followed by gasification and methanation of urban woody waste and woody forest biomass (Pathways $4 \& 5$ ). Note that LCNG production costs from gasification and methanation production pathways (4\&5) are expected to improve with future technological advances in processing, which will only improve their cost advantage.

Given their resource availability and low cost, Pathways 2 and $4 \& 5$ are identified as most-likely early pathways for decarbonizing natural gas supply in California. Landfill gas (2) offers a GHG 
emission reduction potential of about $67 \%$ compared to fossil $\mathrm{CNG}$, while gasification of urban wood waste and woody forest biomass (4\&5) allow for a GHG emission reduction of approximately $86 \%$.

For a more detailed evaluation of the efforts required to commercialize LCNG in California, additional work building on the present study is recommended:

- Quantify local and regional feedstock supply curves based on detailed resource cost analysis as well as their distance from existing natural gas supply infrastructure (transmission pipelines, etc.).

- Characterize transition issues associated with the LCNG supply network as demand increases over time.

- Integrate analysis of life-cycle GHG emissions with respect to byproduct markets, evolving (e.g., decarbonizing) electricity grids, and anticipated LCNG production and supply technology improvements over time.

- Perform more detailed financial analyses with respect to investor types, pricing mechanisms, and policy drivers such as the low carbon fuel standard.

- Assess the potential market and opportunities for national and international trade of biomass or LCNG for use in transportation applications in California.

- Assess the trade-off in supporting infrastructure deployment between public refueling stations for LCNG vehicles compared to privately-owned refueling infrastructure for CNG fleets. 


\section{References}

Åhman, Max. 2010. "Biomethane in the Transport Sector-An Appraisal of the Forgotten Option.” Energy Policy 38(1):208-17. http://dx.doi.org/10.1016/j.enpol.2009.09.007.

ANL (Argonne National Laboratory). 2015. "The Greenhouse Gases, Regulated Emissions, and Energy Use in Transportation (GREET) model.” https://greet.es.anl.gov/.

Apt, Jay, Adam Newcomer, Lester B. Lave, Stratford Douglas, and Leslie Morris Dunn. 2008. An Engineering-Economic Analysis of Syngas Storage. DOE/NETL-2008/1331. Pittsburgh: National Energy Technology Laboratory. https://www.netl.doe.gov/File\%20Library/Research/Energy\%20Analysis/Publications/DOENETL-2008-1331-EngEconAnalySyngasStorage-FinalRpt.pdf.

Bahreinian, Aniss, Eva Borges, Jesse Gage, Bob McBride, Gordon Schremp, Ysbrand van der Werf Gary, and Yowell Bahrenian. 2016. Transportation Energy Demand Forecast, 2016-2026. CEC-200-2015-008-SD. Sacramento: California Energy Commission. http://docketpublic.energy.ca.gov/PublicDocuments/15-IEPR10/TN210539_20160226T101946_Transportation_Energy_Demand_Forecast_20162026.pdf.

Bengtsson, Selma, Erik Fridell, and Karin Andersson. 2012. "Environmental Assessment of Two Pathways towards the Use of Biofuels in Shipping." Energy Policy 44:451-63.

http://dx.doi.org/10.1016/j.enpol.2012.02.030.

Bordelanne, Olivier, Micheline Montero, Frédérique Bravin, Anne Prieur-Vernat, Olga OlivetiSelmi, Hélène Pierre, Marion Papadopoulo, and Thomas Muller. 2011. "Biomethane CNG Hybrid: A Reduction by More Than $80 \%$ of the Greenhouse Gases Emissions Compared To Gasoline." Journal of Natural Gas Science and Engineering 3(5):617-24.

http://dx.doi.org/10.1016/j.jngse.2011.07.007.

Brinkman, Norman, Michael Wang, Trudy Weber, and Thomas Darlington. 2005. Well-toWheels Analysis of Advanced Fuel/Vehicle Systems - A North American Study of Energy Use, Greenhouse Gas Emissions, and Criteria Pollutant Emissions. Argonne, IL: Argonne National Laboratory. https://greet.es.anl.gov/files/4mz3q5dw.

Burnham, A., J. Han, A. Elgowainy, and M. Wang. 2013. Updated Fugitive Greenhouse Gas Emissions for Natural Gas Pathways in the GREET Model. Argonne, IL: Argonne National Laboratory. https://greet.es.anl.gov/files/ch4-updates-13.

CARB (California Air Resource Board). 2016. “CA-GREET 2.0 Model.” Last updated May 6. http://www.arb.ca.gov/fuels/lcfs/ca-greet/ca-greet.htm.

DOE (U.S. Department of Energy). 2011. U.S. Billion-Ton Update: Biomass Supply for a Bioenergy and Bioproducts Industry. Oak Ridge, TN: Oak Ridge National Laboratory. http://energy.gov/sites/prod/files/2015/01/f19/billion ton update 0.pdf.

_. 2015. "DOE H2A Production Analysis." Version 3.1.

https://www.hydrogen.energy.gov/h2a production.html. 
E3 (Energy and Environmental Economics). 2014. Decarbonizing Pipeline Gas to Help Meet California's 2050 Greenhouse Gas Reduction Goal. San Francisco: Energy and Environmental Economics.

Edwards, R., J-F. Larive, and J-C. Beziat. 2011. Well-to-Wheel Analysis of Future Automotive Fuels and Powertrains in the European Context. Brussels: European Commission Joint Research Centre Institute for Energy and Transport. http://iet.jrc.ec.europa.eu/aboutjec/sites/iet.jrc.ec.europa.eu.about-jec/files/documents/wtw3_wtw_report_eurformat.pdf.

EIA (Energy Information Administration). 2016. "Henry Hub Natural Gas Spot Price." Last modified October 19. https://www.eia.gov/dnav/ng/hist/rngwhhdA.htm.

Han, Jeongwoo, Marianne Mintz, and Michael Wang. 2011. Waste-to-Wheel Analysis of Anaerobic-Digestion-Based Renewable Natural Gas Pathways with the GREET Model. ANL/ESD/11-6. Argonne, IL: Argonne National Laboratory. https://greet.es.anl.gov/files/wasteto-wheel-analysis.

Hsu, Ying-Kuang, Tony VanCuren, Seong Park, Chris Jakober, Jorn Herner, Michael FitzGibbon, Donald R. Blake, and David D. Parrish. 2010. "Methane Emissions Inventory Verification in Southern California." Atmospheric Environment 44(1):1-7. http://dx.doi.org/10.1016/j.atmosenv.2009.10.002.

Jeong, Seongeun, Dev Millstein, and Marc L. Fischer. 2014. "Spatially Explicit Methane Emissions from Petroleum Production and the Natural Gas System in California." Environmental Science and Technology 48(10):5982-90. http://dx.doi.org/10.1021/es4046692.

Kenney, Kevin L., Kara G. Cafferty, Jacob J. Jacobson, Ian J. Bonner, Garold L. Gresham, J. Richard Hess, Leslie P. Ovard, William A. Smith, David N. Thompson, Vicki S. Thompson, Jaya Shankar Tumuluru, and Neal Yancey. 2013. Feedstock Supply System Design and Economics for Conversion of Lignocellulosic Biomass to Hydrocarbon Fuels: Conversion Pathway: Biological Conversion of Sugars to Hydrocarbons -The 2017 Design Case. INL/EXT13-30342. Idaho Falls: Idaho National Laboratory. https://inldigitallibrary.inl.gov/sti/6013245.pdf.

Melaina, M.W. 2015. "SERA Scenarios of Early Market Fuel Cell Electric Vehicle Introductions: Modeling Framework, Regional Markets, and Station Clustering." NREL/PR5400-64395. Presented at the 2015 ICEPAG Conference, Irvine, California, March 23. http://www.nrel.gov/docs/fy15osti/64395.pdf.

Melaina, M.W., O. Antonia, and M. Penev. 2013. Blending Hydrogen Into Natural Gas Pipeline Networks: a Review of Key Issues. NREL/TP-5600-51995. Golden, CO: National Renewable Energy Laboratory. http://www.nrel.gov/docs/fy13osti/51995.pdf.

Mintz, M., J. Han, M. Wang, and C. Saricks. 2010. Well-to-Wheels Analysis of Landfill GasBased Pathways and Their Addition to the GREET Model. ANL/ESD/10-3. Argonne, IL: Argonne National Laboratory. https://greet.es.anl.gov/files/xkdaqgyk0. 
Murphy, J.D., and N. Power. 2009. "Technical and Economic Analysis of Biogas Production in Ireland Utilising Three Different Crop Rotations.” Applied Energy 86(1)25-36. http://dx.doi.org/10.1016/j.apenergy.2008.03.015.

Murray, Brian C., Christopher S. Galik, and Tibor Vegh. 2014. Biogas in the United States: An Assessment of Market Potential in a Carbon-Constrained Future. Durham, NC: Nicholas Institute for Environmental Policy Solutions, Duke University. https://nicholasinstitute.duke.edu/sites/default/files/publications/ni_r_14-02 full pdf.pdf.

Nesbitt, Kevin, and Daniel Sperling. 1998. "Myths Regarding Alternative Fuel Vehicle Demand by Light-Duty Vehicle Fleets." Transportation Research Part D: Transport and Environment 3(4):259-69. http://dx.doi.org/10.1016/S1361-9209(98)00006-6.

NREL (National Renewable Energy Laboratory). 2016. "The Hydrogen Financial Analysis Scenario Tool." http://www.nrel.gov/hydrogen/h2fast/. Accessed October 19.

Orsi, Francesco, Matteo Muratori, Matteo Rocco, Emanuela Colombo, and Giorgio Rizzoni. 2016. "A Multi-Dimensional Well-to-Wheels Analysis of Passenger Vehicles in Different Regions: Primary Energy Consumption, $\mathrm{CO}_{2}$ Emissions, and Economic Cost." Applied Energy 169:197-209. http://dx.doi.org/10.1016/j.apenergy.2016.02.039.

Patterson, Tim, Sandra Esteves, Richard Dinsdale, and Alan Guwy. 2011. "An Evaluation of the Policy and Techno-Economic Factors Affecting the Potential for Biogas Upgrading for Transport Fuel Use in the UK." Energy Policy 39(3):1806-16.

http://dx.doi.org/10.1016/j.enpol.2011.01.017.

Smith, Margaret, and John Gonzales. 2014. Costs Associated With Compressed Natural Gas Vehicle Fueling Infrastructure. DOE/GO-102014-4471. Washington, D.C.: U.S. Department of Energy. http://www.afdc.energy.gov/uploads/publication/cng_infrastructure_costs.pdf.

Smyth, Beatrice M., Jerry D. Murphy, and Catherine M. O’Brien. 2009. "What is the Energy Balance of Grass Biomethane in Ireland and Other Temperate Northern European Climates?" Renewable and Sustainable Energy Reviews 13(9):2349-60.

Thamsiriroj, T., H. Smyth, and J.D. Murphy. 2011. “A Roadmap for the Introduction of Gaseous Transport Fuel: A Case Study for Renewable Natural Gas in Ireland." Renewable and Sustainable Energy Reviews 15(9):4642-51.

van der Werf, Ysbrand. 2016. Personal communication with Ysbrand van der Werf, California Energy Commission, May 10.

Waller, Michael G., Eric D. Williams, Schuyler W. Matteson, and Thomas A. Trabold. 2014. "Current and Theoretical Maximum Well-to-Wheels Exergy Efficiency of Options to Power Vehicles with Natural Gas." Applied Energy 127:55-63. http://dx.doi.org/10.1016/j.apenergy.2014.03.088. 
Wang, M. 1996. GREET 1.0 - Transportation Fuel Cycle Model: Methodology and Use. ANL/EST-33. Argonne, IL: Argonne National Laboratory.

https://greet.es.anl.gov/files/c4z3r4c2. 


\section{Appendix A: Production and Utilization Pathways}

Seventeen techno-economic pathways were generated for the production of low carbon natural gas. In general the modeled processes fall within the following categories:

- Gasification + methanation

- Gasification to hydrogen for blending in gas pipelines

- Anaerobic digestion (waste water treatment plant sludge and agricultural)

- Water electrolysis to hydrogen for blending in gas pipelines

- Water electrolysis to hydrogen at retail stations with blending into CNG vehicle tanks.

All pathways based on H2A cases use Version 3.1 of those cases, and they use standard H2A financial assumptions. Many of the pathways already have peer-reviewed H2A case studies, which were leveraged. Cases without existing case studies used published process information that was then processed with the $\mathrm{H} 2 \mathrm{~A}$ model framework.

\section{Production Technologies}

\section{Central Biomass Gasification of Woody Forest Biomass}

The current pathway is derived from the H2A case study "Current (2010) Hydrogen from Biomass via Gasification and Catalytic Steam Reforming." The future pathway is derived from the H2A case study "Advanced (2025) Hydrogen from Biomass via Gasification and Catalytic Steam Reforming." Both the current and future systems are based on the Battelle/FERCO indirectly heated biomass gasifier, conventional catalytic steam reforming, water gas shift, and pressure swing adsorption purification. The indirectly heated biomass gasifier uses hot sand circulating between the char combustor and the gasifier to provide the heat necessary for gasification. Steam is used as the fluidizing gas; no oxygen (as pure oxygen or air) is fed to the gasifier. The biomass feedstock is assumed to be a woody biomass, represented as hybrid poplar.

The current system is assumed to be using technologies available as of 2015. The future system is considered to be an established " $\mathrm{n}$ "th" plant design, not a first-of-a-kind or pioneer plant. Each system is designed to produce about $150,000 \mathrm{~kg} /$ day of hydrogen and, with a $90 \%$ operating capacity factor, is assumed to produce about $140,000 \mathrm{~kg} /$ day in practice.

The underlying $\mathrm{H} 2 \mathrm{~A}$ case studies were augmented to analyze either a subsequent methanation process or blending of hydrogen into natural gas pipelines.

\section{Central Biomass Gasification of Urban Wood Waste}

Gasification of urban wood waste obtained from municipal solid waste uses the same models as biomass gasification. Municipal solid waste content is primarily woody biomass, although its sourcing is different than fresh-cut forest products. The two pathways are differentiated only by the different feedstock sourcing.

\section{Anaerobic Digesters (WWTP and Agricultural Waste)}

H2A case files were not available for these pathways. Process and cost data were taken from published studies of the technology, Murray (2014). These pathways utilize biological reactors 
(digesters), which allow naturally occurring bacteria to anaerobically consume hydrocarbons, lipids, and proteins present in feedstock such as sludge from waste water treatment plants or manure from agricultural activities. Agricultural waste feedstock considered swine, beef, and dairy operations. Product gas from a digester contains high levels of $\mathrm{CO}_{2}$, moisture, and sulfur species, which are removed prior to obtaining pipeline-quality gas. The gas is pressurized and injected into distribution pipelines. Notably, the gas could also be used on-site for farming operations and digester temperature maintenance.

\section{Landfill Gas}

H2A case files were not available for this pathway. Process and cost data were also sourced from the Nicholas Report (Murray 2014). Landfill gas is produced when anaerobic bacterial consumption of organic matter occurs in sealed landfills. The gas has similar composition as an anaerobic digester but also has a notable additional contaminant of siloxanes. Clean-up of landfill gas has similar unit operations as that for anaerobic digesters, with an additional handling for siloxanes. Gas is cleaned, dried, and compressed for injection into pipelines. Note that often landfill gas is used for on-site power generation and sometimes for export to the grid.

\section{Central Electrolysis}

H2A case files were leveraged for central electrolysis. Two published cases were used that reflect 2010 technology status as well as 2025 DOE technology performance projections. Electrolysis uses water and electric power to generate hydrogen and oxygen. Generated hydrogen is dried, compressed, and made ready for either injection into pipelines or for methanation reactor for further processing.

\section{Distributed Electrolysis}

H2A case files were leveraged for distributed electrolysis. Two published cases reflect 2010 technology status as well as 2025 technology projections. Electrolysis uses water and electric power to generate hydrogen and oxygen.

\section{Conversion Methods (Fuel Pathway)}

\section{Blend Hydrogen Into Pipelines up to 5\%}

Production pathways that yield pure hydrogen were considered as a means to decarbonize natural gas in pipelines via direct blending. This concept has been demonstrated in Europe and shows feasibility for hydrogen blending in pipelines up to as much as $10 \%$ without significant impact on existing natural gas industrial users and consumer appliances. The level of hydrogen blending is sufficiently low to avoid impact on pipeline and end-use materials. Natural gas odorization is also unaffected at this low blend level of hydrogen.

\section{Central Thermal Methanation}

Methanation pathways were evaluated as well as a back-end process for pathways producing either pure hydrogen or syngas containing hydrogen and carbon monoxide. Methanation of hydrogen-producing pathways (electrolysis) requires a supplemental $\mathrm{CO}_{2}$ stream to provide carbon for methane production. Such a stream was not explicitly defined, but was instead assigned a typical commodity price of $\$ 20$ per ton. Cost and operating specifications for methanation were obtained from a DOE/NETL report on the subject, Apt et al. (2008). 
Specifications were incorporated into H2A models to provide integrated process technoeconomic projections.

\section{Blend Hydrogen On Site up to $20 \%$}

Generated hydrogen is dried, compressed, and blended up to $20 \%$ by volume in natural gas for dispensing to CNG vehicles. CNG vehicles have been shown to perform at higher efficiency and lower emissions with such a blend due to the combustion property improvement from hydrogen (higher flame speed and advanced ignition timing). 